\title{
Coping with the Time Dimension in Products Liability
}

\author{
James A. Henderson, Jr. $†$
}

Traditional policy analyses of strict products liability for manufacturing defects liave generally assumed that knowledge of product-related risks and attitudes toward such risks remain constant through time. Although maccurate, these assumptions of constancy have been relatively harmless. Liability rules have been adopted that appear to allocate the accident costs associated with manufacturing defects fairly and in ways that promote allocative efficiency. During the last decade, however, with the growth in importance of product liability cases involving defective product design and manufacturer's failure to warn, it has becolne increasingly clear that the traditional assumptions regarding the constancy of knowledge and attitudes are inadequate. Indeed, a significant percentage of the problems courts encounter in deciding whether producers slould be hable for allegedly defective designs and allegedly inadequate warnings arises from the fact that both knowledge and attitudes regarding product-related risks cliange through time. Between the time a product is distributed in commerce and the time its defectiveness is determined in court, previously unknown hazards, or techniques for reducing known hazards, may be discovered. Moreover, design and marketimg decisions that were consistent with prevailing attitudes toward product-related risks at the time of distribution may be inconsistent with prevailing attitudes when the claim for recovery is hitigated.

Traditionally, judicial decisions concerning product designs and marketing decisions have been reached by focusing on the knowledge and attitudes that prevailed at the time of original distribution. In recent years, however, as the practical significance of post-distribution changes in knowledge and attitudes has coine to be recognized, courts and commentators have begun to question these traditional approaches. Einphasizing the trend away froin negligence-based liability toward strict hability in products cases, a growing number of judges and scholars have concluded that courts should consider time-of-trial knowledge of product-related hazards, at least, in determining the reasonableness of a inanufacturer's earlier design and marketing decisions.

$\dagger$ Professor of Law, Boston University School of Law. A.B. 1959, Princeton University; LL.B. 1962, LL.M. 1964, Harvard University. 
No one, however, has attempted to bring together all of the fact patterns involving post-distribution changes in knowledge and attitudes in order to formulate a consistent policy approach. Instead, the tendency has been for each fact pattern to be considered in isolation, thereby increasing the chances that courts will react inconsistently. Moreover, until recently almost no one seriously considered the implications of taking into account post-distribution shifts in public attitudes toward product-related risks in determining the reasonableness of manufacturers' design and marketing decisions.

Prompted by the beginnings of what may become a trend favoring judicial reliance on hindsight in cases involving the design and marketing of products, this Article examines the various suggestions by courts and commentators for coping with the changes in knowledge and attitudes in design and warning cases. More specifically, this Article addresses the question of whether courts should rely upon hindsight by applymg knowledge and attitudes prevailing at the time of trial in judging the reasonableness of design and marketing decisions reached years earlier. Part I identifies the varieties of hindsight by describing the different types of post-distribution changes in knowledge and attitudes. Part II examines the extent to whicl questions of judicial reliance on hindsight have been addressed by courts and cominentators. Part III suggests the appropriate answers to these questions froin both a theoretical and a practical perspective. The Article concludes that, on balance, judicial reliance on hindsight is unwarranted, and offers a statutory solution to some of the problems courts encounter in trying to cope with the time dimension in these cases.

I

\section{THE VARIETIES OF HINDSIGHT}

In designing and marketing a product, a manufacturer makes a number of choices affecting both the risks and the benefits associated with the product. These choices are influenced not only by the manufacturer's knowledge of the pliysical characteristics of the product, includimg the risks they present, but also by the manufacturer's perceptions of the attitudes of those wlio will use and consume the product or otherwise be affected by it. Both knowledge and attitudes change through time. In theory, knowledge could either decrease or increase, and attitudes could become eitler more tolerant or less tolerant towards risks. In fact, knowledge tends to increase and attitudes tend, or at least have tended in recent years, to become less tolerant toward product-related risks. This Article will focus on these more typical changes in knowledge and attitudes that cause a manufacturer's design and marketing choices that were acceptable when made to be- 
come unacceptable, in the sense that the saine choices would be deemed unreasonable if made at the time of trial.

Whenever courts in products liability actions rely on time-of-trial knowledge and attitudes in judging design and marketimg decisions made years earlier, they may be said to be relymg on hindsight. The types of post-distribution changes that present opportunities for courts to rely on hindsight fall imto four basic categories: (1) post-distribution increases in knowledge regarding design-related hazards; (2) post-distribution increases in knowledge regarding the availability of risk reduction measures; (3) post-distribution increases in the public's aversion to product hazards; and (4) post-distribution decreases in the general pubhic's aversion to techurques for reducing product risks. The first two relate to changes in knowledge; the last two concern shifts in attitudes.

The most dramatic post-distribution changes are imcreases in knowledge regardimg product design hazards. Typically, a prescription drug $^{1}$ beheved at the time of distribution to be harmless is later discovered to cause harm to a significant percentage of consumers. ${ }^{2}$ The manufacturer's response to discovery of a previously unknown liazard will vary with the circunistances. The inanufacturer may be able to redesign the product to eliminate the hazard; or, alternatively, the manufacturer may lack sufficient knowledge of the hazard to redesign the product to make it safer. ${ }^{3}$ In the latter event, if the product is not suffi-

1. The prescription drug cases include Dalke v. Upjohn Co., 555 F.2d 245 (9th Cir. 1977); Sahnon v. Parke, Davis \& Co., 520 F.2d 1359 (4th Cir. 1975); Sindell v. Abbott Labs, 26 Cal. 3d 588, 607 P.2d 924, 163 Cal. Rptr. 132, cert. denied, 101 S. Ct. 286 (1980); Stevens v. Parke, Davis \& Co., 9 Cal. 3d 51, 507 P.2d 653, 107 Cal. Rptr. 45 (1973); Cochran v. Brooke, 243 Or. 89, 409 P.2d 904 (1966). Another significant category of cases involves industrial chemicals and pollutants. See, e.g., In re "Agent Orange" Prod. Liab. Litigation, 635 F.2d 987 (2d Cir. 1980) (Vietnain veterans allege injury froin use of "Agent Orange" defoliant in war); Borel v. Fibreboard Paper Prods. Corp., 493 F.2d 1076 (5th Cir.), cert. denied, 419 U.S. 869 (1974) (asbestos poisoning contracted froin 33 years of exposure to asbestos); Heck v. Beryllium Corp., 424 Pa. 140, 226 A.2d 87 (1966) (berylliuin poisoning from 15 years of exposure).

2. When this Article refers to the "discovery" of a product hazard or a risk reduction technique, to some extent it indulges in inetaphor. Increases in knowledge typically come in the form of small accretions in understanding; dramatic breakthroughs occur, but not frequently. See note 22 infra.

3. This Article refers to a hazard that is inherent in the design of a product as a "product design hazard" or a "generic hazard." Product design hazards should be contrasted with hazards posed by manufacturing defects. Manufacturing defects can be described by "defect rates," which means that a certain number of defects, and hence defect-related accidents, can be expected out of every thousand products or uses. But in theory, every product could be examined and the defects, or inost of them, could be discovered and eliminated. A "zero defect rate" would be prohibitively costly in most instances, but it could be approximated technically. With respect to many designrelated risks, especially the risks presented by drugs and other chemicals, all that is possible to know are the functional analogs of the defect rates: that a correlation exists between the use of a certain product and the incidence of a ccrtain adverse result. Limits on knowledge prevent a prediction regarding which of the applications of the product will result in hurn. For the signifi- 
ciently useful it will be withdrawn from the market; if it is sufficiently useful to warrant its continued consumption, the manufacturer will warn potential consumers of the risks accompanying the use of the product. In either event, the central question in connection with unknown product design hazards is whether the manufacturer should be held strictly hable to persons who consume or are affected by the product before the hazards are discovered. ${ }^{4}$

Post-distribution mcreases in knowledge are also reflected in cases involving techniques discovered after distribution by which product designs may be altered so as to reduce risks known to be present, but thought to be nnavoidable, at the time of distribution. ${ }^{5}$ The most frequent cases of this sort involve developments of materials and techmiques of design and manufacture that reduce the hazards associated with a product without reducing the product's utility. ${ }^{6}$ Soine persons may be injured by the product before the risk reduction technique becomes available; others are mjured after such tinne, while using older durable products. In any event, the decision to purchase the product is, by hypothesis, made before the post-distribution increase in knowledge. Thus, even when the increase in knowledge occurs before the purchaser is mjured, he may find himself economically "locked

cance of this difference between product design hazards and manufacturing defects, see note 114 and accompanying text infra. An example of the difficulties courts encounter im reviewing admimistrative regulations based on statistical correlations of this sort is Ethyl Corp. v. Environmental Protection Agency, 541 F.2d 1 (D.C. Cir.), cert. denied, 426 U.S. 941 (1977) (review of EPA's determination that lead emissions presented significant risk of harin to the health of urban populations).

4. The emphasis here is on strict liability. Whether the producer will be liable for breacl of his subsequent duty to use reasonable care to recall products or to warn of later-discovered hazards is a different question, see note 17 infra, and will not be addressed in this Article. The question of whether the manufacturer should be held strictly liable to imjured persons who consume the product with knowledge of the risks of injury is also beyond the scope of this analysis. See notes 113-14 infra.

5. For a recognition of this second type of post-distribution increase in knowledge and its relationship to the first, see Schwartz, Foreword: Understanding Products Liability, 67 CALIF. L. Rev. 435, 482 (1979) [hereinafter Schwartz]. See also Twerski \& Wemstein, $A$ Critique of the Uniform Product Liability Law-A Rush to Judgment, 28 DRAKE L. REv. 221, 227 (1978-79).

6. In the nost general sense, increases im knowledge about a product fall imto one of two categories-knowledge about lrazards and knowledge about benefits-whicl1 reflect the risk-utility axis of classical cost-benefit analysis. Increases in knowledge of hazards and increases in knowledge about risk reduction techniques are just two of a large number of categories of cases in which increases im knowledge cause judgments about product designs to change for the worse. A technological breakthrough that increases a product's benefits without reducing its risks, for example, might cause the orignal design to be judged unreasonable im comparison with the newer, improved design. As is made clear in a subsequent analysis, however, the present emphasis on these two case categories-increases in knowledge of hazards and increases in knowledge of risk reduction techniques-helps to simplify the analysis without detracting from its rigor. Interestingly, although Professor Schwartz recognizes that both unknown risks and unknown risk reduction techniques lave a "matter-of-degree character," Scliwartz, supra note 5, at 487, he does not recognize this fundamental way im which the two types of cases are related. 
into" the older, more dangerous technology.7

The question of when a risk reduction measure becomes "available" to a manufacturer is not easy to answer. As with post-distribution increases in knowledge of product hazards, mcreases in knowledge of methods to reduce or avoid those hazards may come slowly and by degrees. A inanufacturer may know in theory that certain hazards are avoidable, and yet be unable to act on that knowledge because economically feasible applications of the theory have not yet been developed. ${ }^{8}$ The central question in this analysis is whether a manufacturer should be held strictly liable for its nonnegligent failure to incorporate risk reduction measures which became available only after the distribution of products that cause accidents.

Post-distribution changes in attitudes reflect the fact that as society has become increasingly safety conscious, product-related hazards are tolerated less, and risk reduction measures, witl their associated costs, ${ }^{9}$ are tolerated more. ${ }^{10}$ The inost frequent examples of post-distribution changes in attitudes occur in cases involving older product designs that reflect the indifference to product-related risks prevalent years ago. A durable product designed many years ago, even if it were a leader in safety at that tine, probably presents levels of risk that are unaccept-

7. See note 142 and accompanying text infra.

8. See, e.g., Garst v. General Motors Corp., 207 Kan. 2, 484 P.2d 47 (1971), in which the plaintiff claimed that an earth scraper should have been equipped with a steering mechanisin that would have permitted quicker response in emergencies. The plaintiff rehed on expert testimony to contradict defendant's argument that "it couldn't be done." Reversing a plaimtiff's judgment, the Kansas Supreme Court concluded: "With respect to the steering system utilized by the General Motors scraper, the record discloses no better solution [to the slowness of response] was known to the imdustry." Id. at 16, 484 P.2d at 58. See also Brady v. Melody Homes Mfr., 121 Ariz. App. 253, 589 P.2d 896 (1978); Wiska v. St. Stanislaus Social Club, Inc., 1979 Mass. App. Ct. Adv. Sh. 1291, 390 N.E.2d 1133 (1979).

A significant difference between hazards and risk reduction techniques is that the forner damages the physical welfare of users and consumers regardless of whether the hazards are known or even suspected of being present. In contrast, the fact that a risk reduction technique has not been developed prevents that technique from improving the welfare of those who use the product. Thus, it can be said that hazards of which we do not know can nevertheless hurt us, whereas risk reduction techniques of which we do not know cannot hclp us. For the significance of this difference between the effects of these different types of ignorance, see notes 152-55 and accompanying text infra.

9. These costs include not only investments in safety equipinent but also reductions in efficiency. Thus, a safety guard on a productive machine not only requires a commitment of resources to its own production and installation, but may also require a commitment of resources in the forn of lower production from the machine.

10. The assertion of a trend favoring risk aversion is admittedly based on what might be termed "official indicators," such as increases in governmental safety regulations, rather than on surveys of public attitudes. If it is wrong-if, for example, an opposite trend has begun in the direction of risk preference-the implications for the present analysis are serious. See note 169 and accompanying text infra. 
able in hight of current attitudes. ${ }^{11}$ Some of these cases involve postdistribution mcreases in knowledge of risk reduction techniques ${ }^{12}$ as well as changes in attitudes. Often, safety devices were not included in machines designed years ago because such devices were viewed as impediments to efficient production, not because the knowledge necessary for their implementation was unavailable. ${ }^{13}$ This Article considers whether courts should rely on hindsight by bringing to bear time-oftrial attitudes towards product hazards and risk reduction techniques in judging the reasonableness of manufacturers' design and marketing decisions.

\section{II}

\section{The Extent to Which Courts and Commentators} Have Advocated Judicial Reliance on Hindsight

Until recently, courts and commentators, applying a neghigence standard of hability, have unanimously supported the view that rehance on hindsight is mappropriate $\mathrm{m}$ judging the reasonableness of manufacturers' product design and inarketing choices. ${ }^{14}$ In design and warning cases based on neghigence, the issue for decision is whether a reasonable manufacturer would have adopted a safer design, or would have marketed the product differently, given the circumstances-including existing attitudes toward safety and limits on knowledge-that confronted the defendant manufacturer. ${ }^{15}$ In theory, a finding of man-

11. The paradigm would be a thirty-year-old punch press originally distributed without a barrier guard to prevent inadvertent injury to the operator's hands.

12. See note 8 supra.

13. In Ward v. Hobart Mfg. Co., 450 F.2d 1176 (5th Cir. 1971), the plaintiff argued that the defendant manufacturer of a meat grinder that injured the plaintiff in 1967 should have equipped the grinder with a permanent guard when it was originally distributed in 1948. The court of appeals reversed a judgment for the plaintiff, concluding:

Perhaps if [the defendant] had been conducting its business in a vacuum in 1948 its knowledge of the risk of operating the grinder without a guard might be more significant. But in 1948, [the defendant], as it is today, was a participant in the American system of free enterprise which thrives on competition. Safety is not the only criterion a manufacturer considers when designing a product. He looks as well to the expectations and desires of the public. Such expectations are also an important consideration in determining what is a reasonable standard in a products hability case. There was evidence to the effect that in 1948 the public preferred a grinder without a guard-in order to speed up the grinding process.

Id. at 1184-85. See generally Twerski, Rebuilding the Citadel: The Legislative Assault on the Common Law, 15 Trial 55, $57-58$ (1979) [hereinafter cited as Twerski].

14. See, e.g., Stonehocker v. General Motors Corp., 587 F.2d 151 (4th Cir. 1978) (duty on automobile manufacturer to nse due care in designing car); Ward v. Hobart Mfg. Co., 450 F.2d 1176 (5th Cir. 1971) (erroneous finding of neghigent design of meat grinder); Pontifex v. Sears, Roebuck \& Co., 226 F.2d 909 (4th Cir. 1955) (no hability without establishing negligence in design of lawn nower); Birnbaum, Unmasking the Test for Design Defect: From Negligence (10 War. ranty] to Strict Liability to Negligence, 33 VAND. L. REv. 593 (1980).

15. The traditional test for negligence is whether a reasonable person would have acted differently under the saine circumstances that confronted the defendant, including the same access to 
ufacturer negligence cannot rest on the fact of post-distribution changes in either attitudes or knowledge. ${ }^{16}$ Such changes may give rise to postdistribution duties to recall products or to warn users of previously unknown risks, ${ }^{17}$ but the imposition of these post-distribution duties does not necessarily indicate that the defendant was negligent in originally designing and inarketing the product.

Moreover, courts refuse to hold producers strictly liable for failing to incorporate design features that were not within "the state of the art," that is, within the limits of the knowledge of risk reduction techniques available at the time of distribution. ${ }^{18}$ The refusal to rely on hindsight is also characteristic of both implied warranty principles ${ }^{19}$ and the strict products liability provisions of the Restatement of Torts, Second. ${ }^{20}$ Although the focus of attention under warranty and strict

relevant information. See, e.g., The Nitroglycerine Case, 82 U.S. (15 Wall.) 524 (1872); Greene v. Sibley, Lindsey \& Curr Co., 257 N.Y. 190, 177 N.E. 416 (1931). See generally W. Prosser, HANDBOOK OF THE LAW OF TORTS \$ 31, at 146 (4th ed. 1971). This same approach is taken in products habihity cases. See, e.g., Brady v. Melody Homes Mfr., 121 Ariz. App. 253, 589 P.2d 896 (1978); Woodhill v. Parke, Davis \& Co., 79 Ill. 2d 26, 402 N.E.2d 194 (1980).

16. Evidence of such changes is admissible as circumstantial proof that alternative, safer designs were feasible earlier. See note 24 and accompanying text infra. But even if safer alternatives were available earher, the manufacturer was not necessarily negligent in refusing to adopt thein. See Ward v. Hobart Mfg. Co., 450 F.2d 1176 (5th Cir. 1971); Brady v. Melody Homes Mfr., 121 Ariz. App. 253, 259, 589 P.2d 896, 902 (1978).

17. See, e.g., Braniff Airways, Inc. v. Curtiss-Wright Corp., 411 F.2d 451 (2d Cir.), cert. denied, 396 U.S. 959 (1969); Sterling Drug, Inc. v. Yarrow, 408 F.2d 978 (8th Cir. 1969); Noel v. United Aircraft Corp., 342 F.2d 232 (3d Cir. 1964). Several federal statutes impose upon manufacturers and other sellers duties to notify of defects or to recall defective products. See, e.g., National Traffic and Motor Vehicle Safety Act of 1966, 15 U.S.C. $\$ \$ 1411-1420$ (1976); Consumer Product Safety Act of 1966, 15 U.S.C. $\$ \S 2051-2081$ (1976); Federal Boat Safety Act of 1971, 46 U.S.C. $\$ 1464$ (1976). See generally Patterson, Products Liability: The Manufacturer's Continuing Duty to Improve His Product or Warn of Defects After Sale, 62 ILL. B.J. 92 (1973); Comment, Products Liability: Post-Sale Warnings, 1978 ARIz. ST. L.J. 49.

18. See Wiska v. St. Stanislaus Social Club, Inc., 1979 Mass. App. Ct. Adv. Sh. 1291, _ n.8, 390 N.E.2d 1133, 1138 n.8. See generally O'Donnell, Design Litigation and the State of the Art: Terminology, Practice and Reform, 11 AKron L. REv. 627 (1978); Raleigh, The "State of the Art" in Product Liabiliy: A New Look at an Old "Defense," 4 OHIo N.L. REv. 249 (1977). The phrase "state of the art" has several ineanings. See P. KEETON, D. OwEN \& J. MONTGOMERY, Products LIABILITY AND SAFETY 465 (1980). Some courts and commentators use it synonymously with "industry custom." When used in that way, the phrase refers not to the limits of technical knowledge but to the industry's shared attitudes toward product safety.

19. Sections 2-314 and 2-725 of the Uniform Commercial Code make clear that a breach of implied warranty of merchantability occurs at the time nonconforming goods are delivered. Although a court might nevertheless judge a product design's "fitness for ordinary purposes" in light of time-of-trial knowledge and attitudes, the time-of-sale emphasis in the Code renders judicial reliance on hindsight less likely.

20. The text of the highly influential $\$ 402 \mathrm{~A}$ of the RESTATEMENT (SECOND) OF TORTS (1965) establishes a time-of-sale perspective, and Comments $j$ and $k$ to that section inake clear that design and marketing choices are to be judged on the basis of the circuinstances as they would have appeared to a reasonably prndent manufacturer at the time of distribution. Indeed, the similarity between the traditional neghgence approach to design and inarketing cases and the strict liability approach outlined in the Restatement in regard to judicial hindsight has led observ- 
liability theories purportedly shifts from the reasonableness of the conduct of the manufacturer to the reasonableness of the product design itself, traditional applications of warranty and strict hability in design cases have been imdistinguisliable from applications of negligence principles. ${ }^{21}$

Of course, even under traditional negligence theories of liability for defective product designs, a manufacturer is responsible for anticipating advances in knowledge that are reasonably foreseeable at the time it makes product design and marketing choices. ${ }^{22}$ Moreover, a manufacturer is leeld to a standard of reasonable care in testing new product designs for hidden hazards and in discovering and adopting risk reduction techniques. ${ }^{23}$ In considering these duties of care to test and improve product designs, evidence of time-of-trial knowledge of hazards and risk reduction techniques is admissible as circumstantial proof thiat the defendant could liave, and should have, discovered thein before distributimg the product that liarned the plaintiff. ${ }^{24}$ However, the traditional test for liability is the reasonableness of the defendant's design and marketing decisions at the time the product was distributed.

ers to conclude that the two approaches are substantially identical. Kiely, The Art of the Neg. lected Obvious in Products Liability Cases: Some Thoughts on Llewellyn's The Common Law Tradition, 24 DE Paul L. Rev. 914, 929-32 (1975); $c$. Volkswagen of America, Inc. v. Young, 272 Md. 201, 220-21, 321 A.2d 737, 747 (1974) (\$ 402A not applicable to design defect cases). See also Jones v. Hutchinson Mfg. Co., 502 S.W.2d 66, 69-70 (Ky. 1973).

21. This statement is true of actions against manufacturers. See note 20 supra. But in actions against other defendants, strict liability represents a very different basis of liability. A retailer is much more likely to be held hable in design and warning cases under a strict liability than under a negligence approach. See Henderson, Manufacturers' Liability for Defective Product Design: A Proposed Statutory Reform, 56 N.C.L. REv. 625, 635 (1978).

22. Some of the best examples of a manufacturer's duty to anticipate advances im knowledge are found in the prescription drug cases. Frequently, knowledge that a drug may cause a liarmful side effect begins with suspicions that gradually increase im credibility. See, e.g., Sterling Drug, Inc. v. Yarrow, 408 F.2d 978, 987 (8th Cir. 1969), in whicls the court of appeals describes a typical sequence: "The evidence . . . strongly supports the finding of the trial court that, beginning in 1957, medical publications suggested some connection between retinal eye clianges and [defendant's drug]; that from the medical publications this connection became increasingly evident by the year 1959 and reasonably apparent in the year 1962 . . ."

23. See, e.g. , Banks v. Koehring Co., 538 F.2d 176, 179 (8th Cir. 1976): "When a manufacturer offers a inachine or equipment to the public . . ., the user is entitled to presume that the manufacturer has fully tested the mechanism . . . ."See also Drayton v. Jiffee Chem. Corp., 395 F. Supp. 1081, 1090 (N.D. Ohio 1975).

24. In some jurisdictions planitiffs are allowed to introduce evidence of post-distribution design changes in order to establisl that a safer design was possible earlier. The focus in the decisions and commentary has been on post-accident, rather than post-distribution, changes, but the hindsiglit probleins presented are essentially the same. The leading case is Ault v. International Harvester Co., I3 Cal. 3d 113, 528 P.2d 1148, 117 Cal. Rptr. 812 (1974). See also Chart v. General Motors Corp., 80 Wis. 2d 91, 258 N.W.2d 680 (1977). But see Phillips v. Hudson Co., 79 Mich. App. 425, 263 N.W.2d 3 (1978) (evidence of a pre-accident design change madmissible). The trend may be against admission of such evidence. See Birubaum, Products Liability-Grow. ing Trend to Deny Admission of Post-Accident Remedial Measures, Nat'1 L.J., July 23, 1979, at 18, col. 1 . 
Evidence of subsequent design changes is generally not admissible as direct proof that the defendant's product was neghigently designed or marketed. ${ }^{25}$ It must be conceded, of course, that post-distribution changes im knowledge and attitudes influence the reactions of judges and juries despite all efforts to minimize such effects. Thus, although a jury may be imstructed to evaluate a product design in hight of the circumstances origmally facing the manufacturer, jurors will inevitably bring to bear their own attitudes in reaching decisions. ${ }^{26}$

Perhaps the greatest source of judicial application of today's attitudes to yesterday's design and marketing decisions under traditional hability theories is the retroactive application of post-distribution changes in legal rules of decision. ${ }^{27}$ Recently, for example, the "patent danger rule," which barred recovery for harin caused by obviously dangerous aspects of a product's design, ${ }^{28}$ has been abrogated in a number of jurisdictions. ${ }^{29}$ Clearly, the elimination of the patent danger rule reflects a shift im social attitudes toward design-related risks. ${ }^{30}$ Giving retroactive effect to the decision to abrogate the rule in cases involving products that were distributed in the heyday of the patent

25. See, e.g. , FED. R. Evid. 407, which allows such evidence to prove ownership, control, or feasibility of precautionary measures, but not to prove negligence.

26. On the subject of influences on jury behavior, see generally J. HENDERSON \& R. PEARson, The TORTS Process 303-10 (1975).

27. These retroactive rules applications have two primary sources: (1) the traditional rule giving retroactive apphication to judicial changes in the common law; and (2) the generally recognized rule that a products liability action accrues at the time of imjury or at the time of the plaintiff's first awareness of the imjury, and not at the time of sale. On the first point, see generally Note, The Retroactivity of Minnesota Supreme Court Personal Injury Decisons, 6 WM. MrTCHELL L. REV. 179 (1980). On the second, see Victorson v. Bock Laundry Macl. Co., 37 N.Y.2d 395, 335 N.E.2d 275, 373 N.Y.S.2d 39 (1975). Professor Twerski recognized the problem described in the text, but attributed it entirely to the first source described in this note. See Twerski, supra note 13, at 58. Of the two sources described, this writer believes the second to be more significant than the first. Even if courts were to overrule products liability precedent only prospectively, applications of today's values to yesterday's design choices would oceur in every case where the cause of action accrues after the change in the law.

28. The best known statement in the rule is Campo v. Scofield, 301 N.Y. 468, 472, 95 N.E.2d 802, 804 (1950): "[T]he manufacturer is under no duty to render a machine or other article 'more' safe-as loug as the danger to be avoided is obvious and patent to all." Campo was overruled in Micallef v. Miehle Co., 39 N.Y.2d 376, 348 N.E.2d 571, 384 N.Y.S.2d 115 (1976). See note 30 infra.

29. See, e.g., Mitchell v. Freuhauf Corp., 568 F.2d 1139 (5th Cir. 1978); Brown v. North Am. Mfg. Co., 176 Mont. 98, 576 P.2d 711 (1978); Micallef v. Miehle Co., 39 N.Y.2d 376, 348 N.E.2d 571, 384 N.Y.S.2d 115 (1976). But see Waegli v. Caterpillar Tractor Co., 197 Neb. 82, 251 N.W.2d 370 (1977) (no duty to warn of a known danger). See generally Darling, The Patent Danger Rule: An Analysis and A Survey of Its Vitality, 29 MerCER L. Rev. 583 (1978).

30. It may also reflect an advance in the relevant teclinology. Thus, the New York Court of Appeals in Micallef explained its abrogation of the patent danger rule in terms of teclnological changes rather than attitudinal changes: "Advances in the teclmologies of materials, of processes, of operational means have put it almost entirely out of the reach of the consumer to compreliend why or how the article operates .... Apace with advanced teclinology, a relaxation of the Campo stringency is advisable." 39 N.Y.2d at 385,348 N.E.2d at 577, 384 N.Y.S.2d at 121. 
danger rule imvolves, to no small degree, the apphication of today's attitudes to yesterday's product design decision. ${ }^{31}$

More significant than these indirect apphications of hindsight is the growing support in recent years for direct rehance on hindsight in products liability cases. Led by Deans Keeton ${ }^{32}$ and Wade, ${ }^{33}$ a number of judges and scholars have concluded that today's knowledge of product-related hazards should be relied upon by courts im determining whether a defendant's design and inarketing decisions were reasonable. $^{34}$ The Wade-Keeton test ${ }^{35}$ for liability is whether a reasonable manufacturer, knowing of the design hazards that are known at the time of trial, would have designed and marketed the product im the same marmer as did the defendant. ${ }^{36}$ Liability is strict to the extent that post-distribution imcreases in knowledge reveal hazards of which the defendant manufacturer was not, and of which a reasonable person in the manufacturer's position could not have been, aware.

Advocates of this approach msist that it is consistent with the trend favoring the apphication of strict liability principles in design and warning cases. Under strict liability, the focus is on the product rather than on the conduct of the manufacturer in designing the product. ${ }^{37}$ If the product is proven to have been unacceptably hazardous, then the product is defective whether or not the manufacturer was ninocently ignorant of those hazards. Indeed, it is precisely this willingness to impose

31. See Twerski, supra note 13 , at 58 .

32. See Keeton, Products Liability-Design Hazards and the Meaning of Defect, 10 CUM. L. REv. 294 (1979); Keeton, Product Liability and the Meaning of Defect, 5 ST. MARY's L.J. 30 (1973) [hereinafter cited as Keeton, Product Liability]; Keeton, Manufacturer's Liability: The Meaning of "Defect" in the Manufacture and Design of Products, 20 SYRACUSE L. REV. 559 (1969) [hereinafter cited as Keeton, Manufacturer's Liability]; Keeton, Products Liability-Current Developments, 40 TEX. L. REv. 193 (1961) [hereinafter cited as Keeton, Current Developments].

33. See Wade, On the Nature of Strict Tort Liability for Products, 44 Miss. L.J. 825 (1973) [hereinafter cited as Wade, Liability for Products]; Wade, Strict Tort Liability of Manufacturers, 19 Sw. L.J. 5 (1965) [hereinafter cited as Wade, Liability of Manufacturers].

34. See, e.g., Dougherty v. Hooker Chein. Corp., 540 F.2d 174 (3d Cir. 1976); Suter v. San Angelo Foundry \& Mach. Co., 81 N.J. 150, 406 A.2d 140 (1979); Phillips v. Kinwood Mach. Co., 269 Or. 485, 525 P.2d 1033 (1974); Dickerson, Products Liability: How Good Does a Product Have to Be?, 42 IND. L.J. 301, 331 (1967); Montgounery \& Owen, Reflections on the Theory and Administration of Strict Tort Liability for Defective Products, 27 S.C.L. REv. 803, 843-44 (1976); Schwartz, supra note 5, at 488; Vetri, Products Liability: The Developing Framework for Analysis, 54 OR. L. REV. 293 (1975).

35. The phrase "Wade-Keeton" is used here because it has been used by others and appears to have becoune part of the hiterature. See, e.g., Birnbaum, supra note 14, at $619 \mathrm{n} .125$. Actually, Dean Keeton appears to have first advanced the test. See generally Montgomery \& Owen, supra note 34 , at 843 n.142.

36. See Phillips v. Kimwood Mach. Co., 269 Or. at 492, 525 P.2d at 1036; Keeton, Manufacturer's Liability, supra note 32, at 568; Wade, Liability for Products, supra note 33, at 837-38. See generally Birnbaum, supra note 14, at 618-31.

37. See, e.g., Barker v. Lull Eng'r Co., 20 Cal. 3d 413, 435, 573 P.2d 443, 457, 143 Cal. Rptr. 225, 239 (1978); Schwartz, supra note 5, at 459-64; Birnbaum, supra note 14. 
liability for unknowable hazards that distmguisles strict liability from negligence. ${ }^{38}$ Thus, just as manufacturers are lield strictly liable for harm caused by hidden manufacturing defects even when such defects were not discoverable by the exercise of reasonable care, ${ }^{39}$ manufacturers should be held strictly liable for hidden design hazards. ${ }^{40}$ Advocates of the Wade-Keeton approach insist that holding inanufacturers strictly liable for their ignorance will pressure thein to extend the frontiers of knowledge regarding product-related hazards. ${ }^{41}$ Manufacturers also can insure against unknowable product design liazards, thus providimg sources of coinpensation for innocent victims of product-related accidents. $^{42}$

Although the Wade-Keeton test takes the significant step of advocating reliance on hindsight in cases involving unknowable hazards, it refuses to extend similar treatınent to cases involving post-distribution increases in knowledge of risk reduction measures and post-distribution changes in attitudes. ${ }^{43}$ On the one liand, this refusal may refiect a

38. Advocates of the Wade-Keeton approach point out that except for the liability for unknowable hazards, their tests are essentially negligence tests. See, e.g., Keeton, Products Liability-Inadequacy of Information, 48 TEx. L. REv. 398 (1970) [hereinafter cited as Keeton, Inadequacy of Information].

Under the thesis here proposed, the kind of dangerous conduct that is required as a basis for subjecting the maker to hability is the same kind that is required for recovery on a negligence theory. But the fact that the maker was excusably unaware of the extent of the danger . . . would be entirely irrelevant.

Id. at 407-08. It is important to understand that the element common to neghigence and strict liability in this context is the cost-benefit analysis. Under negligence, the reasonableness of the manufacturer's conduct in designing the product is the issue; under strict liability, the issue is the reasonableness of the design itself. Without reliance on hindsight, to condemn the design is to condemn the designer, and vice versa. See Henderson, Renewed Judicial Confusion Over Defective Product Design: Toward the Preservation of An Emerging Consensus, 63 MinN. L. Rev. 773 (1979) [heremafter cited as Henderson, Judicial Confusion].

39. See, e.g., Greenman v. Yuba Power Prods., 59 Cal. 2d 57, 377 P.2d 897, 27 Cal. Rptr. 697 (1962); RESTATEMENT (SECOND) OF TORTS \$ 402A (1965).

40. See, e.g., Keeton, Manufacturer's Liability, supra note 32, at 570-71:

If there is to be any strict liability at all it seeins reasonably clear that a iniscarriage in the manufacturing process is a proper risk to be allocated to the inaker. It is not equally clear that a risk that is scientifically unknowable should likewise be allocated. On the other hand, I am inclined to the view that all the risks that result in bad products . . . should be allocated to the inaker.

See also Twerski \& Weinstein, supra note 5, at 227-28; Wade, Liability of Manufacturers, supra note 33 , at 14-15.

41. See, e.g., Schwartz, supra note 5, at 484-85; Wade, Liability for Products, supra note 33, at 826; Note, Strict Products Liability: The Irrelevance of Foreseeablity and Related Negligence Concepts, 14 TulSA L.J. 338, 353-54 (1978). On the effects of tort liability on inanufacturers' behavior, see Katz, The Function of Tort Liability in Technology Assessment, 38 U. CINN. L. REv. 587, 634-36 (1969).

42. See, e.g., Montgomery \& Owen, supra note 34, at 844 n.145; Wade, Liability for Products, supra note 33 , at 826.

43. This refusal is more imphicit than explicit in the work of Wade and Keeton. See notes 32-33 supra. In a recent article, Dean Keeton states this conclusion exphcitly. See Keeton, The Meaning of Defect in Products Liability Law-A Review of Basic Principles, 45 Mo. L. REv. 579, 
judgment that increases in knowledge of hazards present different issues for decision. ${ }^{44}$ On the other, the possibility of extending their analyses may not have occurred to the advocates of the Wade-Keeton approach. By focusing on finding unified tests for hability that can be employed in both product design and manufacturing defect cases, ${ }^{45}$ they may not have anticipated the significance of post-distribution changes other than increases in knowledge of hazards because the other post-distribution changes, such as development of risk reduction techmiques, are not particularly relevant in manufacturing defect cases. ${ }^{46}$

Whatever may be the reasons for limiting the Wade-Keeton test to cases involving unknowable hazards, proposals for inore sweeping judicial rehance on hindsight have support. In the last several years coinmentators have urged, ${ }^{47}$ and several courts have held, ${ }^{48}$ that yesterday's design choices should be judged on the basis of today's knowledge of

595 (1980). In Hagans v. Oliver Mach. Co., 576 F.2d 97 (5th Cir. 1978), the plaintiff was injured in 1971 while using an industrial saw manufaetured and sold by the defendant in 1942. The plaintiff's employer bought the saw in 1960 from one of its previous owners. When originally distributed, the saw was equipped with a removable guard that would lave prevented the plaintiffs injury. The guard was still attaehed in 1960, but not at the time of the plaintiff's accident. In reversing a judgment below for the plaintiff, the court of appeals acknowledged the Wade-Keeton test, but it also recognized that a manufacturer inust consider more than safety in designing its product. Although the defendant could liave designed a permanent guard, such a device would lave diminislied the utility of the saw. The court found that the defendant acted reasonably in designing a removable safety guard which permitted the saw to perform a wide range of operations. "Plaintiff offered no evidence that in 1942 a permanent guard assenbly could have been devised which would protect the operator during every woodworking operation performable on the saw." Id. at 100.

44. See Scliwartz, supra note 5, at 488 \& n.291; Twerski \& Wcinstein, supra note 5.

45. See, e.g., Wade, On Product "Design Defects" and Their Actionability, 33 VAND. L. REv. 551,577 (1980): "[One reform] in the law of products liability that require[s] . . . urgent attention . . . is to combine negligence, breach of warranty, and strict liability into a single cause of action for products liability."

46. The presence of a manufacturing defeet inay be determined without resort to a costbenefit analysis; because the feasibility of risk reduction measures is relevant only as an elenent of cost-benefit analysis, it plays no role in fiaw cases. See Henderson, Judicial Review of Manufacturers' Conscious Design Choices: The Limits of Adjudication, 73 ColuM. L. REv. 1531, 1542-50 (1973) [hereinafter cited as Henderson, Judicial Review].

47. See, e.g., Adler, Strict Products Liability: The Implied Warranty of Safety, and Negligence and Hindsight, As Tests of Defect, 2 Horstra L. REv. 581, 603-04 (1974); McClellan, Strict Liability for Drug Induced Injuries: An Excursion Through the Maze of Products Liability, Negligence and Absolute Liability, 25 WAYNE L. REV. 1, 27 (1978); Polelle, The Foreseeability Concept and Strict Products Liability: The Odd Couple of Tort Law, 8 RUTGERs-CAM. L.J. 101 (1976); Scarzafava, An Analysis of Products Liability Defenses in the Aftermath of Hopkins, 9 ST. MARY's L.J. 261 (1977); Note, supra note 41.

48. See, e.g., Matthews v. Stewart Warner Corp., 20 Ill. App. 3d 470, 314 N.E.2d 683 (1974); Cryts v. Ford Motor Co., 571 S.W.2d 683, 689 (Mo. App. 1978); Bailey v. Boatland of Houston, Inc., 585 S.W.2d 805 (Tex. App. 1979), rev'd, 609 S.W.2d 743 (Tex. 1980). In Barker v. Lull Eng'r Co., 20 Cal. 3d 413, 430, 434, 573 P.2d 443, 454, 457, 143 Cal. Rptr. 225, 236, 239 (1978), the court suggested that hindsight may be relied upon in determining the defectiveness of a product design. Professor Schwartz lias concluded that the court's ambignous statements probably condone only reliance on hindsight in cases involving unknown risks. See Schwartz, supra note 5, at 488. 
hazards and risk reduction techniques, and in light of today's attitudes. According to advocates of these inore radical forms of judicial reliance on hindsight, liability will be strict only when manufacturers are denied all opportunity to argue that their design choices were reasonable when made based on existing limits of human foresiglit. Here, the test for liability is whether a reasonable manufacturer at the time of trial would design and market the same product in the same nianner as did the defendant at the time the product was distributed. ${ }^{49}$ Recent statements in support of this approach reflect little appreciation for the implications of the liability test being espoused. ${ }^{50}$ The analysis that follows explores the theoretical and practical implications of reliance on hindsight in these cases.

III

Is Judicial Reliance on Hindsight Justifiable?

\section{A. The Traditional Justifications for Strict Products Liability}

Judicial reliance on hindsiglit amounts to imposnig strict liability on manufacturers for their design and marketing decisions. Indeed, without such reliance it is difficult to see how strict liability for defective designs is any different from liability based on negligence. ${ }^{51}$ Thus, it will facilitate an assessment of reliance on hindsight if the traditional justifications for imposing products liability strictly are briefly reviewed. In general, strict liability is thought to be preferable to negligence because it better enhances social utility by reducing the costs associated with accidents and because it pronotes fairness. Strict liability is believed to increase utility by satisfyning four inajor objectives: encouraging investment $\dot{\mathrm{n}} 1$ product safety, ${ }^{52}$ discouragnig consumption of hazardous products, ${ }^{53}$ reducing transaction costs, ${ }^{54}$ and promoting

49. See Adler, supra note 47, at 603-04:

If the product is judged by the state of the art as it exists or could reasonably exist at the time of the trial, and the product is no longer made and marketed in the same way, or should not be, the product is defective. All the events bearing on that issue would be admissible, imcluding product changes subsequent to injury. Since the safety of the product, not fault, is the issue, compensation should follow, but it would not be exacerbated by the passions of a determination of fault.

See also Scarzafava, supra note 47, at 270-71 (emphasis in original): "Strict liability looks to the product not the manufacturer. Therefore, the ouly relevant question centers upon whether the product is unreasonably dangerous at the time of trial."

50. "The attempt herem has been conceptual and is in need of substantial refinement." Adler, supra note 47 , at 604 .

51. See note 38 and accompanying text supra.

52. See, e.g., La Rossa v. Scientific Design Co., 402 F.2d 937, 943 (3d Cir. 1968); Hoven v. Kelble, 79 Wis. 2d 444, 468, 256 N.W.2d 379, 391 (1977); Twerski \& Weinstein, supra note 5.

53. See generally G. Calabresi, The Cost of Accidents 68-75 (1970); McKean, Products Liability: Trends and Implications, 38 U. CHI. L. REv. 3, 41-42 (1970). 
loss spreading. ${ }^{55}$ The relevance of these utility-related objectives to tort law has been explored elsewhere and will be discussed only briefly here. $^{56}$

Strict hability promotes investunent in product safety, the so-called "risk control" objective, ${ }^{57}$ by imposing hability rules that encourage manufacturers to find ways to reduce or eliminate avoidable product risks. Although in theory this same objective is satisfied by holding inanufacturers hable only for their negligence, ${ }^{58}$ those who advocate strict hability suggest that manufacturers escape a significant portion of neghigence-based hability. An action sounding in neghigence presents the plaintiff with difficult issues of proof, such as what a manufacturer with expertise in the field should have known. ${ }^{59}$ Manufacturers also may be able to destroy adverse test results and frustrate plaintiffs' attempts to demonstrate that the defendant knew of the hazards. ${ }^{60}$ Knowing that the average plaintiff has difficulty in establishing negligence, manufacturers may be willing to bet on escaping hability, or at least large judgments, and thus inay limit their efforts to reduce product risks. A regime of strict liability, which does not consider the inanufac-

54. Sce, e.g., Keeton, Inadequacy of Information, supra note 38, at 408, 409 n.25. Transactions cost reductions are explored in G. CALABRESI, supra note 53, at 225-26.

55. See, e.g., Bachner v. Pearson, 479 P.2d 319, 328 (Alaska 1970); Escola v. Coca Cola Botthing Co., 24 Cal. 2d 453, 462, 150 P.2d 436, 441 (1944) (Traynor, J., concurring); Furrow, Defective Mental Treatment: A Proposal for the Application of Strict Liability to Psychiatric Serv. ices, 58 B.U. L. REV. 391, 414-15 (1978).

56. See notes 52-55 supra. One of the best recent treatments of the policy objectives of strict products liability appears in Owen, Rethinking the Policies of Strict Products Liability, 33 VAND. L. REV. 681 (1980). For a forceful argument that efficiency in the form of judicial cost-benefit analysis cannot provide a rationale for tort law, see Rizzo, Law Amid Flux: The Economics of Negligence and Strict Liability in Tort, 9 J. LEGAL STUD. 291 (1980). For a reply to Rizzo, see Rubin, Predictability and the Economic Approach to Law: A Comment on Rizzo, 9 J. LEGAL STUD. 319 (1980).

57. See Owen, supra note 56, at 711-13.

58. Exposure to liability for negligence will pressure a rational producer to the point where marginal costs of accident avoidance equal marginal costs of accidents. Negligence law should pressure the producer to invest optimally in research for hidden lrazards, i.e. , to the point, but not beyond, where the marginal expected injury costs equal the marginal costs of testing. Even if strict liability were imposed on such a producer, no greater investment in researcl would be made because it would be clieaper for the producer to insure than to keep testing. See Posner, Strict Liability: A Comment, 2 J. Legal STUd. 205 (1973). Under the present system the pressures on manufacturers to control risks are enhanced by the willingness of some courts to allow punitive damages for particularly willful neglect of the manufacturer's duties to test and warn. See, e.g., Giliham v. Admiral Corp., 523 F.2d 102 (6th Cir. 1975), cert. denied, 424 U.S. 913 (1976); Sturm, Ruger \& Co. v. Day, 594 P.2d 38 (Alaska 1979); Toole v. Richardson-Merrell Inc., 251 Cal. App. 2d 689, 60 Cal. Rptr. 398 (1st Dist. 1967); Rinker v. Ford Motor Co., 567 S.W.2d 655 (Mo. App. 1978); Wangen v. Ford Motor Co., 97 Wis. 2d 260, 294 N.W.2d 437 (1980). See generally Owen, Punitive Damages in Products Liability Litigation, 74 MICH. L. REv. 1257 (1976). But see Roginsky v. Richardson-Merrell Inc., 378 F.2d 832 (2d Cir. 1967) (evidence of carelessness, bad judgment, and improper supervision not sufficient to establisli recklessness).

59. See, e.g., Twerski \& Weinstein, supra note 5, at 227-28.

60. Id. 
turer's knowledge, eliminates the practical difficulties involved in litigating a negligence claim. Manufacturers will be less likely to escape hability and will have a greater incentive to invest in efforts to reduce product risks.

Strict liability has also been justified on the ground that it reduces the consumption of risky products by increasing their cost and so placing thein at a disadvantage in the inarket. This second objective, frequently referred to as "market deterrence,"61 rests on the assumption that consumers tend to underassess the risks associated with various products. $^{62}$ Unless consumers are reminded of these risks by price increments reflecting manufacturers' liability insurance costs, including the costs of insuring against accidents not worth trying to prevent, they will overconsume relatively risky products. Lower consumption of these products will result in fewer accidents, thereby reducing the costs of product liability insurance. Unlike the risk control objective, market deterrence is not achieved to the same extent, even in theory, by imposing liability only for negligence: a relatively lazardous product will escape hability if its benefits are sufficient to justify its risks and a reasonable person would not have inade it safer at the time of its distribution. In that event, the product will reflect the relevant avoidance costs, but will not reflect the costs of insuring against those accidents that are not worth trying to prevent.

The third objective traditionally thought to be promoted by strict liability is the reduction of transaction costs, which include the costs of operating the accident reparation system. ${ }^{63}$ Strict liability reduces these costs by simplifying the proof necessary to establish liability. Since the plaintiff need not put forward evidence of the defendant's negligence, often a difficnlt, costly, and time consuming process, the costs of trials under a strict liability rule shonld be lower than they would be under a negligence rule.

The final utility objective concerns reducing dislocation costs that occur when a single individual or business unust bear the full accident

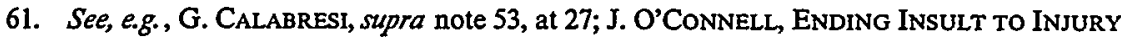
76-80 (1975).

62. The National Commission on Product Safety reached this conclusion in its 1970 final report: "It is difficult to underestimate the knowledge of most consumers about product safety." National Commission on Product Safety, Final Report 63 (1970). See note 30 supra. In Henningsen v. Bloomfield Motors, Inc., 32 N.J. 358, 161 A.2d 69 (1960), the court observed: "Under modern conditions the ordinary layman, on responding to the importuning of colorful advertising, has neither the opportumity nor the capacity to inspect or to determine the fitness of an automobile for use; he must rely on the manufacturer who has control of its construction ...."Id. at 384, 161 A.2d at 83 . It should be observed that the court was speaking of the discovery of defects rather than of an appreciation of the fiaw rate. See note 3 supra.

63. For a theoretical treatment of transaction costs (referred to as "tertiary cost"), see G. CALABRESI, supra note 53, at 225-26. 
loss. The costs of repairing the dainage or replacing what has been lost, whether borne by an unsuccessful plaintiff or by a liable defendant, may financially destroy the loss bearer. The additional social costs represented by the uncoinpensated victim who becomes a public charge, or by the manufacturer who goes into bankruptcy, inust also be counted as costs of accidents. These dislocation costs can be reduced by spreading accident losses among a large number of persons by means of insurance. ${ }^{64}$ In general, manufacturers are believed to be better able to obtain msurance than are consumers, and are assumed to be able to pass on most, if not all, of the insurance costs by raising the prices of products. ${ }^{65}$ Under a neghigence approach, manufacturers who are not negligent escape liability; even very large accident costs caused by dangerous products will not be shifted to defendants who have acted reasonably. ${ }^{66}$ Under strict hability, more of such costs are shifted to manufacturers and their insurers, thus decreasing dislocation costs to the extent of the increased liability. ${ }^{67}$

In addition to the first four objectives aiming at the proinotion of social utility, strict products hability traditionally has been supported on the ground that it responds to shared notions of fairness. This writer confesses to a certain degree of skepticisin regarding the relevance of fairness, as a consideration separate from utility, to the question of whether producers should be held strictly liable. ${ }^{68}$ When a producer is

64. See, e.g., Owen, supra note 56, at 703-07.

65. In his concurring opinion in Escola v. Coca Cola Bottling Co., 24 Cal. $2 \mathrm{~d} 453,150$ P.2d 436 (1944), which is one of the earliest judicial statements in support of strict liability for products manufacturers, Justice Traynor concluded: "The cost of an injury and the loss of time or lealth may be an overwlelming misfortune to the person injured, and a necdless one, for the risk of injury can be insured by the manufacturer and distributed among the public as a cost of doing business." 24 Cal. 2d at 462, 150 P.2d at 441 . See also Cushing v. Rodman, 82 F.2d 864 (D.C. Cir. 1936) (burden of strict liability in implied warranty will be cliarged to the cost of busmcss and thus spread at large in the price of goods).

66. Under a sclreme of liability for negligence, the prices of products will reflect avoidance costs.

67. Writers disagree on the legitimacy of the loss spreading objective as a justification for strict products liability. Thus, one writer asserts: "The primary goals achieved by applying hability . . . are compensation and cost spreading. Deterrence is a secondary goal and it is detached from the ethical constramt of negligence law." McClellan, supra note 47, at 32. Another writer lias reaclied a different conclusion: " '[C]ompensation' and 'risk shifting' should be banned from the lexicon of accepted social policies. The 'risk spreading' rationale should not be used unless a court is willing to justify its use of the judicial forum to redistribute wealth from rich to poor on the arguably fortuitous happenstance of product accidents." Owcn, supra note 56, at 715 .

68. I do not doubt that concepts of fairness play an important role in tort law generally, and more specifically in strict liability for extremely liazardous activities. See Epstem, $A$ Theory of Strict Liability, 2 J. LEGAL STuD. 151 (1973); Fletcler, Fairness and Utility in Tort Theory, 85 HARV. L. REV. 537 (1972). But products liability is clraracterized by a significant element of consent which reduces the moral force of many plaimtiff' claims. See note 78 infra, and text accompanying notes 83 \& 179-80 infra. It is probably no accident that Professors Epstein and Fletcher generally avoid products liability in their treatments of fairness in tort law. 
negligent in designing, lnanufacturing, or marketing a product, it is easy to appreciate the relevance of fairness principles to the question of liability. ${ }^{69}$ But the allocation of accident losses to producers irrespective of fault seems to be primarily a means of reducing social waste rather than a means of achieving fairness. ${ }^{70}$ Yet, the fact that courts and commentators persist in rationalizing strict products liability in terms of fairness strongly suggests that fairness should be examined. ${ }^{71}$ Thus, rather than circumventing fairness in this analysis, or attempting once and for all to settle the question of its relevance to strict products hability, an effort will be made to identify those fairness rationales that seem to support strict liability and to inquire into whether these rationales also support judicial reliance on hindsight.

Of the many fairness rationales relied upon by courts and coinmentators, ${ }^{72}$ three offer possible justifications for strict products liability. All three rationales rely to some extent on imtuition for their support, and all present analytical difficulties. In order to understand these rationales, it will be useful to consider how they support the traditional imposition of strict liability for harm caused by manufacturing defects.

First, strict liability may be justified on fairness grounds because the product that contaims a hidden manufacturing defect that causes harm disappoints the consumer's or user's reasonable expectations with

69. At least if one posits a rational, competent actor, the failure to behave toward others as would a reasonable person intuitively constitutes a wrong. See Fletcher, supra note 68, at 556-64. For the argument that irrational actors should, in fairness, only be held to a "best efforts" standard, see Rodgers, Negligence Reconsidered: The Role of Rationality in Tort Theory, 54 S. CAL. L. REV. 1, 16-23 (1980).

70. Part of this writer's suspicion that fairness does not serve as an independent basis for strict liability arises from the tendency for writers to use fairness terminology to explain utility related principles. For exainple, loss spreading is sometimes advanced as a way of achieving fairness. See, e.g., Escola v. Coca Cola Bottling Co., 24 Cal. 2d 453, 462, 150 P.2d 436, 441 (1944) (Traynor, J., concurring). On the subject of the relationship between principles of utility and fairness, see Dworkin, Is Wealth a Value?, 9 J. LEGAL STUD. 191 (1980); Fletcher, supra note 68; Hubbard, Efficiency, Expectations and Justice: A Jurisprudential Analysis of the Concept of the Unreasonably Dangerous Product Defect, 28 S.C.L. REV. 587 (1977) [heremafter cited as Hubbard, Efficiency]; Kronman, Wealth Maximization as a Normative Principle, 9 J. LEGaL STUD. 227 (1980); Posner, Utilitarianism, Economics and Legal Theory, 8 J. LEGAL STUD. 103 (1979); Symposium on Efficiency As a Legal Concern, 8 HoFSTRA L. REv. 485 (1980).

71. See notes 72-73 infra.

72. It is argued, for example, that because manufacturers profit from their activities they should, in fairness, be required to compensate persons injured by defective products. See, e.g., Suvada v. White Motor Co., 32 Ill. 2d 612, 619, 210 N.E.2d 182, 186 (1965). Another rationale frequently advanced is that because defective products present extraordinary risks, it is only fair that inanufacturers shonld compensate injured victims. See, e.g., Hoven v. Kelble, 79 Wis. 2d 444, 468, 256 N.W.2d 379, 391 (1977); Note, 11 CReIGHTON L. Rev. 1357, 1359 (1978). It is also argued that because consumers rely on suppliers for protection, fairness requires that they be allowed to recover when that protection is not provided. See, e.g., Jerry v. Borden Co., 45 A.D.2d 344, 348-49, 358 N.Y.S.2d 426, 431-32 (1974). 
regard to safety. ${ }^{73}$ The producer may not liave been negligent, and the plaintiff may have understood as a general proposition that mistakes can liappen. However, when the plaintiff lias paid value for the product, he has a riglit to expect that it will not fail dangerously in its intended use. ${ }^{74}$ Moreover, producers typically try to communicate impressions of infallability that create consumer confidence im the product. ${ }^{75}$ Intuitively it seeins appropriate to allow the plaintiff in such a case to claim compensation based on the unfair disappointinent of his reasonable expectations.

Second, strict liability for manufacturing defects may be justified because in distributing its products, some of which contam hidden manufacturing defects, the producer may be said to be deliberately taking the physical well-being of those who are injured by the product. ${ }^{76}$

73. See generally, Hubbard, Reasonable Human Expectations: A Normative Model for Imposing Strict Liability for Defective Products, 29 MERCER L. Rev. 465 (1978); Hubbard, Efficiency, supra note 70; Shapo, A Representational Theory of Consumer Protection: Doctrine, Function and Legal Liability for Product Disappointment, 60 VA. L. REv. 1109 (1974). This expectations rationale is very close to the consumer reliance ratiouale recognized in Jerry v. Borden Co., 45 A.D.2d 344, 358 N.Y.S.2d 426 (1974).

74. This statement of the consumer expectations rationale points up some of the analytical difficulties associated with it. First, by including the element of the plaintiff "paying value," the rationale seems to be limited to purchaser-plaintiff situations and introduces extraneous primciples of restitution for economic harm. For example, are bystanders, who are unlikely to lave "expectations" regarding products of which they are not even aware, entitled to rely on the consumer expectations rationale? Is the inoral force of the plaintiff's argument diminished where it is understood from the outset that defective products will be replaced at no extra cost to the purchaser?

The second analytical difficulty with the consumer expectations rationale is its ambiguity regarding whether the relevant expectations are the actual subjective expectations of purchasers, or the objective expectations of reasonable purchasers. If the former, then are producers with bad reputations for safety to be held to a lower standard than producers with good reputations? If the latter, what are the fairness criteria by which to determine "reasonable expectations"?

The rationale has another analytical difficulty in that it takes little account of the reality that purchasers generally do know that they may receive a defective product and be injured by it. Purchasing and using a product can be likened to going into a casimo and wagering against the remote chance that a particular numnber will "come up." No one expects his number to come up, just as no one expects to win the jackpot in more conventional games of chance. But everyone assumes that soineone will lose, or win, as the case may be. Of course, it can be argued that the purchasers of products do not know the odds involved in every game, and must be reminded by price increments arrived at via strict liability; but that is essentially a utility-based "Inarket deterreuce" rationale. See notes $61-62$ and accompanying text supra. To rise to the dignity of a fairness ratiouale, the significance of consumer ignorance inust go further than merely an imability to assess the odds, and approach a vitiation of consent to take risks due to a failure to perceivc the nature of the game being played.

75. See, e.g., Shapo, supra note 73, at 1129-31. This may be the moral aspect of the consumer expectations ratiouale. The fact that consumers tend to underassess risks supports a market deterrence rationale, see note 62 and accompanying text supra; but since manufacturers encourage underassessments, fairness should be considered as well as utility.

76. Perhaps the most forceful statement of this rationale appears in Cowan, Some Policy Bases of Products Liability, 17 STAN. L. Rev. 1077, 1087-92 (1965). See also LeBel, Intent and Recklessness as Bases of Products Liability: One Step Back, Two Steps Forward, 32 ALA. L. REv. 31 (1980), in which the author refers to "the sense of outrage, frustration, and demoralization that 
The producer is like an actor who shoots into a crowd. The producer, like the shooter, does not know who will be injured; but as surely as the shooter knows that someone will be shot, the producer knows that someone will be injured. Both the shooter and the producer can also estimate the number of victims. The shooter loads his gun with a certam number of bullets, and the producer accepts a certain defect rate when settimg the level of quality control for its products. Having set a defect rate, the producer can predict the number of accidents, and thus, the number of accident victims. Choosing to limit quahity control means accepting a certain number of accidents; so in a sense, the eventual victims of this choice are harmed dehberately. Of course, the shooter is presumably not privileged, and thus commits a battery when he shoots into the crowd. ${ }^{77}$ In contrast, the producer is here assumed to have made the econormically reasonable decision in choosing to limit quality control. Consequently, the producer can be said to be privileged in the sense that it will not be found liable under a system of neghigence even though its conduct caused harm to others. However, there is precedent for holding an actor liable to others for harm deliberately inflicted even when the actor is privileged to act. ${ }^{78}$ The best that can be said for the manufacturer is that it has behaved in an economically rational manner; but that does not alter the fact that its deliberate decision has condemned users and consumers to suffer harm. On this view, the manufacturer should in fairness be required to compensate the injured victims. ${ }^{79}$

accompanies the realization that the lives or physical well-being of a certain number of people have been written off by a manufacturer in pursuit of an economically efficient allocation of resources." Id. at 67.

77. See W. Prosser, supra note $15, \S 8$, at 32 . For the soinewhat radical arguinent that the manufacturer also commits batteries when he sells products soine of which lie knows contain defects, see LeBel, supra note 76.

78. The leading case is Vimcent v. Lake Erie Transp. Co., 109 Minn. 456, 124 N.W. 221 (1910), in which the planitiff recovered for larm to his dock caused when the defendant tied his boat to the dock and kept it tied fast during a storm. The court concluded that under the circumstances the defendant was privileged by necessity to tie the boat up to the dock, but that the defendant should pay the plaintiff for the harm caused by his dehiberate acts. In Vincent, the plaimtiff clearly did not consent to the defendant's actions. The question in the products liability context is whether the producer has a privilege which derives from the consent of product purchasers. If it does, then the Vincent analogy is false and the producer should not be required to pay for the harm caused without fault on his part. Clearly, some victims of product defects, i.e., bystanders, do not consent in the usual sense of the word. To the extent that bystander-plaintiffs have stronger claims based on fairness than do purchaser-plaintiffs, their claims may be based more on the lack of consent than on the deliberateness of the producer's conduct. In that event, they would seem to be relying on the "benefits/burdens" rationale rather than on the "deliberate taking" rationale. See notes 81-83 and accoinpanying text infra.

79. An interesting question is whether the defendant's decision unust be deliberate in order to support a claim for compensation based on fairness. Professor Epstein insists that it need not be deliberate in the sense employed in the text, and that even the actor whose conduct creates a possibility, rather than the certainty, that others will be liarmed can be said to "take" their well- 
Finally, strict liability for manufacturing defects may be justified on fairness grounds because it causes the financial burden of accidents to be borne by those who use, and therefore benefit directly from, the product $^{80}$ From this perspective, the producer is a conduit through which accident costs are shifted from injured persons who do not directly benefit from the product to those persons wlio do. When a defective product distributed by a nonnegligent producer causes an accident in which a nonuser or nonconsumer bystander is injured, the producer who is held strictly liable shifts the costs to those who purchase and use or consume the product. The bystander-plaintiff's claim is supported by the fairness principle that "those who benefit should pay." course, the principle applies only crudely. Some nonusers and nonconsumers benefit indirectly from the use and consumption of the products that cause them imjury. ${ }^{82}$ Also, spreading the costs pro rata on a perproduct rather than on a per-use basis causes some users and consum-

being and should be required to justify his conduct. See Epstein, supra note 68, at 158-59. Notwithstanding Epstein's insistence to the contrary, deliberateness seeins to add to the moral force of the plaintifr's claim. Thus, in Grimshaw v. Ford Motor Co., No. 19-77-61 (Orange County Super. Ct., Cal., order dated Mar. 30, 1978), the jury awarded the plaintiff $\$ 2,841,000$ coinpensatory damages and $\$ 125,000,000$ in punitive damages, based on testimony that the defendant manufacturer had deliberately refused to incur over $\$ 125,000,000 \mathrm{im}$ estimated avoidance costs to save approximately $\$ 50,000,000$ in estimated accident costs. On its face, Ford's decision appears to have been rational. In the minds of the jurors, however, the cold-hearted deliberateness of the decision apparently inade it appear grossly unfair.

80. The closest statement of this rationale in the cases is the assertion by the lllinois Supreme Court in Suvada $v$. White Motor Co. that the manufacturer should be strictly liable because it profits from its activity. 32 III, 2 d 612, 619, 210 N.E.2d 182, 186 (1965). In the present analysis the focus has shifted from a "consumer vs. manufacturer" to a "consumer vs. consuner" perspective. Although he does not speak in terms of benefits and burdens, Professor Fletcher makes a similar point in his analysis of faimess in tort law. He speaks in terms of "nonreciprocal risks"-this is, risks to which one group of actors exposes others without being exposed to similar risks in return. Fletcher, supra note 68 . In the present context of strict products liability, bystanders come the closest of any class of plamtiffs to making a claim based on this view of fairness.

81. One analtyical difficulty with the principle advanced in the text is that it begs the question of whether the victims have consented expressly or implicitly to being affected by the activities in question. If they have consented, then the inoral force of their claims is greatly diminished. The fact that the victims can be said to benefit indirectly from the activities that cause harm may help to raise an inference that consent is at least tacitly present, but the inore basic concept is probably that of consent rather than enjoyment of benefits. See generally Posuer, The Ethical and Political Basis of the Efficiency Norm in Common Law Adjudication, 8 HofsTRA L. REv. 487 (1980) [hereinafter cited as Posner, Efficiency Norm]. For a forceful reply, see Dworkin, Why Efficiency?, 8 HOFSTRA L. REv. 563, 580-84 (1980) [hereinafter cited as Dworkin, Efficiency].

82. This is the other major analytical difficulty with the "benefits/burdens" rationale as it is advanced in the text. For example, when a defective automobile injures a pedestrian, one's first impulse is to treat the plaimtiff as a bystander. But what if the plaintiff owns an automobile which he frequently drives? Or what if the plaimtiff works for the automobile manufacturer? Or what if he owns and operates a retail gasoline outlet? The point is that in a modern, industrialized society nearly everyone exposes others to product-related risks of many kinds, differing ouly in the details, and most inembers of the society derive benefits of one sort or another froin product-related activities. In one extrene view, there are no bystanders to whoin compensation is owcd on the ground of faimess. See Posner, Efficiency Norm, supra note 81. 
ers to bear more, and some less, than their fair share of the burden. Moreover, recovery on the basis of strict liability is not restricted to bystanders; users and consumers also recover for harm caused by manufacturimg defects. However, within these narrow limitations strict liability for manufacturing defects seem to be supported by the "benefits/burdens" fairness primciple.

All three fairness rationales represent responses to situations in which accident costs are imposed on certam persons without their express or tacit consent. ${ }^{83}$ The "benefits/burdens" rationale, with its concern for bystanders who in no way consent to being victims, is most clearly concerned with consent. The other rationales reflect similar perspectives. The "consumer expectations" rationale relies on the assumption that producers, through advertising, entice purchasers into a misplaced sense of security so that the consent seemingly given by purchasers to their exposure to product-related risks is more properly viewed as involuntary. ${ }^{84}$ Fimally, the "deliberate taking" rationale, although it purports to focus on the deliberateness of the manufacturer's quahty control decisions, relies on the idea of nonconsensual "takimg." 85

Traditional strict products liability for manufacturing defects is supported, at least arguably, by both fairness and utility primciples. The analysis that follows determines whether strict hability based on hindsight in design and warning cases is similarly supportable.

\section{B. Should Courts Rely on Post-Distribution Increases in Knowledge of Product Hazards?}

Of the types of hindsight considered in this Article, reliance on post-distribution mcreases im knowledge of hazards is the most widely recognized. A growing number of courts and cominentators is urging that time-of-trial knowledge of hazards be imputed to manufacturers when judging the reasonableness of their design and marketing choices. $^{86}$ That some courts and cominentators lave refused to join

83. In a recent article, Posner argnes that plaintiffs consent even in these cases $I$ have characterized as nonconsensnal. See Posner, Efficiency Norm, supra note 81, at 491-97. His position on this point is attacked forcefully in Coleinan, Efficiency, Utility and Wealth Maximization, 8 HoFSTRA L. REV. 509, 531-40 (1980); Dworkin, Why Efficiency?, 8 HoFstRa L. REV. 563, 574-79 (1980).

84. See notes 74-75 supra.

85. See note 76 supra.

86. See notes 32-34 and accompanying text supra. In 1979, the Council of Europe had before it a proposed directive that called for the producer of an article to be liable for damage caused by a defect in the article, whether or not the producer knew or could have known of the defect. Amendment of the Proposal for a Council Directive Relating to the Approximation of the Laws, Regulations and Administrative Provisions of the Member States Concerning Liability for Defective Products (No. 415) 11, Comm'n of the Eur. Communities (Sept. 26, 1979). 
this trend ${ }^{87}$ and that the Commerce Department's Model Uniform Product Liability Act refuses to condone this type of judicial reliance on hindsight ${ }^{88}$ emphasizes the need for analysis of this issue.

\section{Would Such Reliance Promote Utility?}

An argument frequently advanced in support of this form of judicial reliance on hindsight is that it will help to achieve the "risk control" objective. ${ }^{89}$ Imposing strict liability for unknown hazards sliould pressure manufacturers to invest more heavily in testimg products before releasing them. ${ }^{90}$ Since strict hability eliminates some of the practical difficulties of establishing negligence-based liability, manufacturers will not be so willing to gamble on escaping liability by forgoimg pre-distribution testing and research. ${ }^{91}$ However, imposing strict liability may create dismcentives for manufacturers to reduce risks. For one thing, manufacturers may be discouraged from testing after distribution to discover whether products are causing harm..$^{92}$ Under traditional negligence rules of liability, a manufacturer wlio discovers previously unknown hazards can escape liability by sharmg that information with the public-as when the manufacturer warns prescribing physicians about prescription drugs. ${ }^{93}$ Under strict liability based on hindsight, a manufacturer helps to establish its liability by sliarmg such information, simce greater knowledge raises the standard by which the manufacturer will be judged. To be sure, the longer the manufacturer

87. See, e.g., Borel v. Fibreboard Paper Prods. Corp., 493 F.2d 1076 (5th Cir. 1973), cerr. denied, 419 U.S. 869 (1974); Bailey v. Boatland of Houston, Inc., 609 S.W.2d 743 (Tex. 1980); Birabaum, supra note 35; Epstein, Product Liability: The Search for the Middle Ground, 56 N.C.L. REv. 643 (1978); Hoenig, Product Designs and Strict Liability: Is There a Better Approach?, 8 Sw. U.L. REV. 109 (1976).

88. See 44 Fed. Reg. 62,714, 62,723-25 (1979).

89. See note 41 supra. The most thorough and forceful statenient of this position appears in Schwartz, supra note 5, at 484-85.

90. See note 41 supra.

91. See notes 58-60 and accompanying text supra.

92. Certainly in a state that has a statute of repose that bars claims after a stated number of years after distribution, a nanufacturer will benefit from discovering hazards later rather than earlier. See notes 188-89 and accompanying text infra. Even in states without such statutes, nanufacturers would be reluctant to help dig their own graves. See Schwartz, supra note 5, at 484 \& n.277. Indeed, manufacturers could be expected to invest in research aimed at demonstrating that their products did not have side effects.

93. See, e.g., Woodhill v. Parke, Davis \& Co., 79 III. 2d 26, 402 N.E.2d 194 (1980); Smith v. E.R. Squibb \& Sons, 405 Mich. 79, 273 N.W.2d 476 (1979); Cochran v. Brooke, 243 Or. 89, 409 P.2d 904 (1966). See generally, Merrill, Compensation for Prescription Drug Injuries, 59 VA. L. Rev. 1, 29-50 (1973). But see Hamilton v. Hardy, 37 Colo. App. 375, 549 P.2d 1099 (1976) (manufacturer of prescription drug has duty to warn patient directly; physician's failure to warn will not insulate manufacturer froin hability). In rare instances, such as mass immunizations where patients are administered drugs without a doctor's prescriptiou, courts have held that patients inust be warned directly. See, e.g., Reyes v. Wyeth Labs, Inc., 498 F.2d 1264 (5th Cir.), cerf. denicd, 419 U.S. 1096 (1974). 
distributes a product that turns out to be hazardous, the greater will be its total exposure to liability; ${ }^{94}$ therefore, the manufacturer might have an imcentive to continue to test, to find out if the product should be discontinued or recalled. However, the manufacturer might decide that it is better to discontinue or reduce post-distribution efforts to determine whether its products are hazardous, so that it will be judged by a low standard of knowledge in the future. Although some increases in knowledge of hazards come from other sources, such as government studies, much of the research coines from private enterprise. ${ }^{95}$ Strict liability may discourage this important source of research and development.

Moreover, if manufacturers are held strictly liable based on knowledge acquired after the distribution of the product, they may be pressured to be too cautious in bringing new products to market. ${ }^{96}$ Manufacturers are under economic pressures to market their new products quickly. ${ }^{97}$ However, this pressure may be countered if manufacturers beheve that strict hability exposes thein in fact to greater liability than in theory they should bear. This can occur in cases where the question of whether a previously unknown product hazard caused the plaintiff's harm must be resolved on the basis of circumstantial evidence such as a statistical correlation between use of the defendant's product and the type of harin suffered by the plamtiff. Since a direct causal link cannot be shown between the product and the harin, the defendant may be found hable in cases where the product did not in

94. In Ault v. International Harvester Co., 13 Cal. 3d 113, 528 P.2d 1148, 117 Cal. Rptr. 812 (1974), the court admitted evidence of a post-accident design modification, despite the defendant's argument that such a ruling wonld discourage manufacturers from improving their designs. The court concluded that manufacturers would have strong imcentive to improve dangerous designs to rednce their overall hability. The same point applies in the context of post-distribution efforts to discover hazards. To be sure, the discovery of a previously unknown hazard cannot reduce the manufacturer's hability for drugs already consumed. But the longer the hazard remains hidden, the greater the number of people who will be hurt. See note 92 and accompanying text supra. Interestingly, in an analysis otherwise disposed toward strict hability for unknown hazards, Professor Schwartz demies the relevance of this point. See Schwartz, supra note 5, at 484 n.277.

95. Professor Schwartz argues that most of the information about unknown hazards comes not from manufactnrers, but from suppliers of raw materials, and thus these disincentives are not significant. See Schwartz, supra note 5, at 485. However, this writer does not share Professor Schwartz's optimism that competition in the market will supply much increased knowledge of hazards.

96. This is an argument frequently advanced in both the decisions and the commentaries. E.g., Leibowitz v. Ortho Pharmaceutical Corp., 244 Pa. Super. Ct. 418, 433, 307 A.2d 449, 458 (1973); Connolly, The Liability of a Manufacturer for Unknowable Hazards Inherent in His Product, 32 lNs. CounseL J. 303, 306 (1965); Comment, The Diminishing Role of Negligence in Manufacturers' Liability for Unavoidably Unsafe Drugs and Cosmetics, 9 ST. MARY's L.J. 102, 112 (1977).

97. In theory, of course, mannfactnrers will not invest in safety beyond the point of diminishing retnrns. The market pressures referred to in the text would prevent them from investing too heavily in research and testing. See note 58 supra. 
fact cause the harm. ${ }^{98}$ If such excess liability were likely, manufacturers would invest too heavily in testing products prior to nnarketing, resulting in the waste of scarce resources. ${ }^{99}$ This excessive investment in testing would delay the marketing of new products. The costs of delay would be borne in part by consumers denied the benefits of these products. ${ }^{100}$

The point here is not that manufacturers held strictly liable for unknown hazards necessarily would abandon post-distribution efforts to test for hazards, or that important new products would never reach the market. More nrodestly, the point is that the answer to the question of how manufacturers would alter their behavior in testing and marketimg products is less clear than proponents of strict liability for unknown hazards have claimed. It is possible that the net effect of imposing strict hability in the form of judicial hindsight would be an increase, rather than a decrease, in social waste.

Judicial rehance on post-distribution increases in knowledge would also fail to achieve the market deterrence objective. One may seriously doubt that the premise of the nuarket deterrence objectivethat consumers tend to underestimate product-related risks-is valid as to many of the products that are involved in unknown hazard cases. ${ }^{101}$ Even if it is assumed that reminders of risks would be helpful in many cases, a system of strict liability for unknown hazards would not supply such reminders. The likelihood of such risks being discovered in the

98. See, e.g., Estep, Radiation Injuries and Statistics: The Need for a New Approach to Injury Litigation, 59 MiCH. L. REv. 259 (1960):

Every person [exposed to an excessive dose of radiation,] including those whose leukemia results from natural causes rather than the defendant's radiation source, can "prove" that "more probably than not" defendant's source "caused" his particular case . . . . If 100,000 persons receive [an excessive] dose, 214 will get leukemia . . . and can hold the defendants legally liable under existing rules, although defendants "caused" only 107 of the cases.

Id. at 279.

99. This is the opposite situation froin the one in which inanufacturers escape a portion of their liability for neghigence and therefore invest too little in product testing. See note 59 and accoinpanying text supra. Consistent with the earlier analysis of the efficiency effects of negligence and strict liability, the objective is to achieve optimal, not naximum, safety. See notes 5759 and accompanying text supra. Spending too much on safety is as socially wasteful as spending too little.

100. One commentator has recently pointed out that im comrection with prescription drugs the costs of increased testing are also borne by those who are used as "guinea pigs" in the prcdistribution tests: "If drug safety could be achieved through more extensive testing, the price could not be judged by monetary cost alone. There is a huinan cost that falls primarily on the incarcerated, the indigent, and the ill." Note, The Liability of Pharmaceutical Manufacturers for Unforeseen Adverse Drug Reactions, 48 FordhaM L. Rev. 735, 756 (1980).

101. With regard to prescription drugs, for example, doctors can peform the role of "professional risk assessors" on behalf of their patients. See, e.g., Mahr v. G.D. Searle \& Co., 72 Ill. App. 3d 540, 561-62, 390 N.E.2d 1214, 1229-30 (1979). Some courts and commentators have questioned whether doctors are capable in this regard. See, e.g., Stevens v. Parke, Davis \& Co., 9 Cal. 3d 51, 507 P.2d 653, 107 Cal. Rptr. 45 (1973); Merrill, supra note 93, at 104-05. 
future cannot be insured against with sufficient accuracy to support a system of unarket deterrence. ${ }^{102}$ Instead of being reflected differentially on a product-by-product basis, as occurs to soine extent with insurance for manufacturing defects, ${ }^{103}$ the costs of insuring against the losses associated with unknown generic hazards would be spread generally among new products, thereby reducing the likelihood that consumers would choose among new products on the basis of relative insurance costs. $^{104}$ To soine extent, differentiation annong broader categories of products would be possible. Prescription drugs and industrial chemicals, for exainple, would reflect higher insurance costs associated with unknown design hazards than would automobiles and household appliances. However, even if some differentiation were possible annong broad product categories, differentiation among products within each category would not be possible.

Moreover, as imprecise as the cost allocations in such a system would be, there would be little opportunity to adjust them based on new knowledge of product hazards. Whenever it is determined that a product is unacceptably hazardous, the product is either withdrawn or marketed in a more restricted inanner. ${ }^{105}$ The product's past cannot be retrieved; the product-or at least the inanner of marketing the product-has no future. Thus, the only allocative adjustinent available to a manufacturer held strictly hable as a result of the discovery of a product hazard is to charge the liability costs that exceed prior estinnates, or insurance coverage limits, to subsequent users of different products, or to persons putting the same product to different uses. ${ }^{106}$

102. See generally Connolly, supra note 96, at 307; Rizzo, supra note 56, at 307-09.

103. A significant difference between manufacturing defects and product design hazards is that the manufacturer's knowledge about the risks presented by the former does not change through time, whereas knowledge of the risks associated with the latter does change, sometimes dramatically. Manufacturing defects liability insurance costs tend to be spread across numbers of products, depending on the rating practices of insurers and the extent to whicl liability is imposed on defendants who produce several products; but the objective of general deterrence is probably achieved in connection with manufacturing defects. For a description of the insurance rating procedures for products liability, see INTERAGENCY TASK FORCE ON PRODUCT LIABILITY, U.S. DeP'T OF COMMERCE, FInAl RePort V-9 to V-17 (1977) [heremafter cited as Final RePORT]; Morris, Enterprise Liability and the Actuarial Process-The Insignificance of Foresight, 70 YALE L.J. 554, 569-74 (1961).

104. To establislı design defect ratcs rather than manufacturing defect rates, insurers would have to pool the experience of many more producers of many more types of products over longer periods to obtain statistically significant numbers of losses. The effect would be to differentiate far less among product types.

105. For a vivid description of one sucl episode, see Rheimgold, The MER/29 Story-An Instance of Mass Disaster Litigation, 56 CALIF. L. REv. 116 (1968).

106. This assumes that the later-incurred hability costs can effectively be passed through to the users of other products produced by the firm. See note 65 supra. If these costs cannot be passed on, then they will be borne by the owners of the firm, some of whom derived no benefit from the earher product distributions, or by the accident victims of an insolvent, uninsured defendant. This tendency to force subsequent consumers of different products to pay for the acci- 
The picture that emerges from this analysis of the market deterrence effect of strict hability for unknown hazards is one of a clumsy cost allocation system unable to differentiate among products except in the grossest terms. Subsequent users and consumers will be forced to pay for losses incurred by previous consumers of different products. Bleak as this picture is, it is probably optimistic unless significant change is made in the test for hability advanced by advocates of judicial rehance on hindsight for unknown product hazards. A coniparison to the market deterrence effect of strict liability for manufacturing defects illustrates why the Wade-Keeton strict liability test would fail to accomplish even a clunsy form of market deterrence.

Strict liability for inanufacturing defects is based in part on the argument that consumers will overconsunie risky products unless they are reminded of the risks in the prices of new products. ${ }^{107}$ Consumption of risky products is not eliminated by imposing strict liability; it is merely reduced to the efficient point where margimal benefits cqual margimal real costs. ${ }^{108}$ To eliminate overconsuinption, strict hability must be imposed for all the harm caused by manufacturing defects, even when the plaintiff fully appreciated the possibility of a defect and bought the product anyway. Unless liability for all defect-causcd harn is imposed, product prices will not adequately refiect their shares of accident costs, aud thus will not provide to consumers at the margin an

dent costs incurred by previous consumers of products no longer on the market would be exacerbated if products liability coverage is written on an "occurrences" or "claims made" basis rather than on a "products distributed" basis. When insurance is written on a "products distributed" basis, it covers the liability associated with the products in question, no matter when the accidents occur or the tort claims are inade. Insurance written on an "occurrenccs" basis covers the liability for product-related accidents occurring within the period. "Claims made" insurance covers liability for the claims made during the coverage period. "Claims made," and to a lesser degree "occurrences," covcrage las the effect of allocating costs associated with unknown hazards to later users of different products. In effect, these forms of coverage reduce the underwriting uncertamties connected with unknown hazards by abandoning any atteinpt to allocate the accident costs associated with product use and consumption against the users and consumers exposed to the relevant risks. Most products liability insurance today is written on an "occurrences" basis, although there may be a trend favoring "claims made." See FINAL REPORT, supra note 103, at V5 to V-8; Kroll, "Claims Made"-Industry's Alternative: "Pay As You Go" Products Liability Insturance, 1976 INs. L.J. 63.

107. See note 62 and accompanying text supra.

108. This effect may be illustrated by a diagram. In figure 1, below, the solid horizontal curve $M R C P$ is the inarginal real cost curve for product $P$, the broken horizontal curve $M A C P$ is the marginal apparent cost curve for product $P$, and the slanting curve $D P$ is the demand curve for product $P$. 
effective reminder of defect-related risks. ${ }^{109}$

The Wade-Keeton test for liability would hold manufacturers liable only for those injuries that are proximately caused by product de-

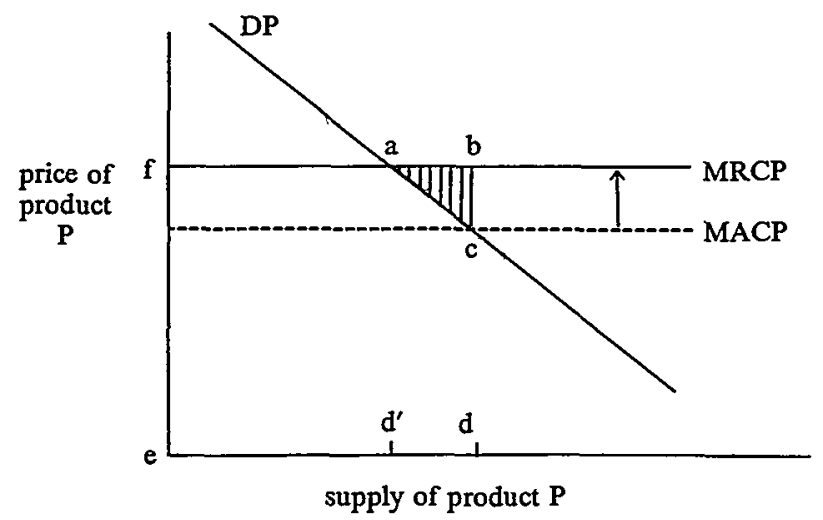

Figure 1

Before the imposition of strict liability, when consumers perceived the costs of consumption as $M A C P$, product $P$ was consumed to point $d$, at a total social cost represented by the rectangular shape $f b d e$ and a total social benefit represented by the shape facde. The shaded triangular area $a b c$ represents the social waste associated with the consumption of $P$-the extent to which the costs associated with $P$ exceed its benefits, because consumers underassessed accident costs.

Imposing strict liability on the producer of $P$ causes the curve $M A C P$ to rise to $M R C P$ consumers can no longer ignore the costs of accidents. Consumption of $P$ falls from point $d$ to point $d^{\prime}$ eliminating the shaded triangle of social waste associated with the earlier consumption of $P$.

109. Thus, in figure 1 in note 108 supra, by hypothesis all of the consumers to the left of point $a$ ou the demand curve $D P$ would have consumed product $P$ even if they liad correctly assessed the real costs from the beginning. But if their shares of the flaw-related accident costs are not included, the price rise in product $P$ will be great enough to deter only a portion of the consumers along the curve $D P$ between points $a$ and $c$. Thus, in fignre 2 , below, if the producer of product $P$ is held hable only for the harm caused to the "deterrable" consumers to the right of point $a$, then the marginal apparent cost curve $M A C P$ will rise only to $M A C P^{\prime}$. Consumption of $P$ will fall only to point $d^{\prime \prime}$, and the reduction in social waste will be only the darkly shaded trapezoid betweeu $M R C P$ and $M A C P$. This represents only a part of the social waste associated with the overconsumption of product $P$. 
sign hazards that were unknown at the time of distribution. ${ }^{110} \mathrm{~A}$ plaintiff would be required to show that he was in fact injured by a previously unknown hazard, and also that he would not have chosen to consume the product, or would have consumed it so as to avoid injury, had he known of the hazard." Under this approach, the "hiddenness" of the hazard is the proximate cause of the plaintiff's injury: but for the hiddenness of the hazard, the plaintiff would not have consuined the product and so would have avoided the harm. If inanufacturers are held hable only for injuries that are proximately caused by unknown design hazards, the price of the product will reflect only the costs of compensating plaintiffs who estabhish proximate causation. The price of the product will not reflect the total accident costs associated with its use which, as with manufacturing defects, include losses to consumers unable to establish that they would not have consumed the product had they fully appreciated the risk of injury. The resulting signal to consumers who would choose not to consume at a price that reflects all the accident costs will be too weak to deter thein froin consuming.

The signal to these inarginal consuiners could be made strong enough if liability were imposed for all the harm caused by unknown hazards, even where the products would have been consuined if the hazards had been known to the consumers. Although this more expan-

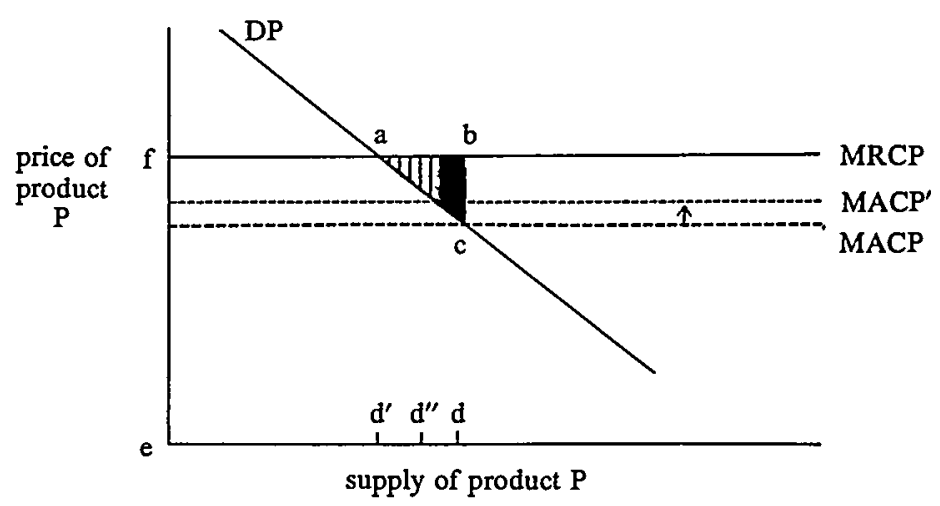

Figure 2

Unless it is possible to sell product $P$ at different prices to different categories of consumers depending on their abilities to assess costs accurately, all of the flaw-related accident costs must be included if the underassessors at the inargin are to be deterred.

110. See, e.g., Keeton, Inadequacy of Information, supra note 38, at 413-15.

111. Some courts assist plaintiffs in failure-to-warn cases with a rebuttable presumption that if an adequate warning had been given, the user or consumer would have acted differently. See, e.g., Reyes v. Wyeth Labs, Inc., 498 F.2d 1264 (5th Cir.), cert. denied, 419 U.S 1096 (1974); Nissen Trampoline Co. v. Terre Haute First Nat'l Bank, 332 N.E.2d 820 (Ind. App.), rev'd on other grounds, 265 Ind. 457, 358 N.E.2d 974 (1976). Such a presumption in this context would reduce, but not eliminate, the difference between the Wade-Keeton "negligence with hindsiglıt" approach and the strict liability/market deterrence approach here being considered. 
sive approach is needed to fulfill the market deterrence objective, it is not advocated by the Wade-Keeton analysis of strict hability. One reason that advocates of the Wade-Keeton approach refuse to extend the limits of strict hability for unknown hazards may be the imphications that a more expansive approach would have for the question of extending hability for known product design hazards. If the plaintiff does not have to show that but for the hiddenness of the design hazard he would not have used the product, then strict liability will be imposed when the plaintiff might have used the product even if he had known of the design hazard. If liability can be supported for harm that would have occurred even if the plaintiff had known of the hazard, there is little reason to require the plaintiff to show that he did not know of the hazard. Then, strict liability can also be imposed in cases involving known design hazards whicl cause injuries to consumers fully aware of the hazards. To be sure, unknown hazards are impossible for users and consuuners to weigh when deeiding to use or consume. However, the difficulties of deciding are not significantly diminished by knowing of the hazards. Consumers still confront the difficult choice of using the product and taking their chances of being injured, or not using it and forgoing its benefits. ${ }^{12}$ If an expansive approacl to strict liability for unknown hazards is adopted in order to achieve inarket deterrence, it is difficult to deny recovery to the consunner who is injured as a result of his decision to consume a product known to be accompanied by a design risk that could be avoided only by a refusal to consune. ${ }^{13}$ However, although some commentators have suggested that producers be held strictly liable in these situations of known but unavoidable product design hazards, ${ }^{114}$ courts liave refused to allow plaintiffs to recover

112. Often these benefits may be necessities to the consumer, e.g., a life-saving drug. See text accompanying notes $151-52$ infra.

113. The consumer in that case is confronted with essentially the same choice as is the consumer of products that may have manufacturing defects. Just as a producer would not escape liabihty for manufacturing defects by marketing his products with the admonition, "Notice: this product may contain a defect that will result in harn-use or consume at your own risk," see Henningsen v. Bloomfield Motors, Inc., 32 N.J. 358, 161 A.2d 69 (1960), so a producer should not escape hability by putting consumers to the saine choice regarding unavoidable generic risks.

114. See Merrill, supra note 93. Dean Merrill would impose strict liability on the manufacturer for drug-related imjuries unless it is shown that the negligence of someone-physician, patient, or drug retailer - caused the imjuries. Such an approach would impose liability for unknown hazards, but it would also impose liability for known hazards that consumers and their physicians cannot avoid through the exercise of reasonable care. Dean Merrill limits his strict liabihity approach to prescription drugs. Could a similar approach be taken with respect to all products? The problem would be to develop a test for user and consumer negligence. For exainple, when the user of a knife cuts himself, he may or may not have been negligent. Under present law, the plaintiff in the "slipping knife" case does not recover, because he cannot establish that a knife is defective merely because it is capable of cutting someone. See Restatement (SECOND) of TORTs § 402A, Comment i (1965). If Dean Merrill's test were extended to the knife situation, some plaintiffs would be allowed to recover on a finding that they were not negligent. His test 
when they are injured while using or consuming products with full knowledge of such design hazards. ${ }^{115}$

Would imposing strict liability for unknown hazards reduce the transaction costs represented by the costs of litigation? In theory, such reliance on hindsight might simplify trials and thereby reduce transaction costs of each claim. ${ }^{116}$ As a practical matter, however, transaction costs might not change. Although the Wade-Keeton strict liability test would eliminate the question of whether a reasonable manufacturer would have discovered the hazard, ${ }^{117}$ it would retain the question of whether a reasonable consumer in the plaintiff's position would have acted differently. ${ }^{118}$ Moreover, the plaintiff might introduce inuch the same evidence in a negligence case and a strict liability case. For example, the plaintiff probably would have to use statistical correlations relied on as circumstantial proof of causation for strict liability, ${ }^{119}$ and could have used the same facts to prove that a prudent manufacturer would have discovered the hazards and warned of thein. ${ }^{120}$ The jury instructions would probably be shorter under strict liability; but the proof at trial, and hence the important transaction costs, would be substantially the same.

It remains to consider whether imposing strict liability for unknown hazards would accoinplish the objective of spreading accident

might work in connection with prescription drugs because of the high percentage of instances in which risks can be avoided only by deciding not to consune, and because the conduct of prescribing physicians can be judged against the standards of the inedical profession. See generally McCoid, The Care Required by Medical Practitioners, 12 VAND. L. REv. 549 (1959). However, in cases like the "shpping knife," neither of these factors is present. This writer believes it is appropriate in that type of design case to place the burden on the plaintiff to show that the design was unreasonably dangerous. See Hcnderson, Judicial Confusion, supra note 38.

115. See Restatement (SECOND) OF TORTS $\S 402 A$, Comment k (1965).

116. See Keeton, Manufacturer's Liability, supra note 32, at 570.

117. Professor Schwartz has observed:

[T]he art form of a lawsuit seems poorly suited to accounplish either the confirmation or the denial of suspicions [that the inanufacturer could have discovered the liazard earlier], given the lapse of time between the product's sale and the product lawsuit, and given the elusiveness of the "should liave known" issue. Taken in combination, these practical observations are syınpathetic to liability [for unknown hazards]: the difference between knowledge-now and knowledge-then inay be something that it is intelligent for litigation to ignore.

Schwartz, supra note 5, at 487 (footnote omitted).

118. See notes 110-11 and accompanying text supra.

119. See note 98 and accoinpanying text supra.

120. In soine cases, of course, the causal link between the product and the plaintiff's larm will be clear. But in nuany cases it will not; all that will be known at the time of trial is that the product contributes to an abnormally high incidence of adverse experiences. See note 98 and accoinpanying text supra. Plaintiffs in such cases will introduce proof tending to slow the growing confidence of medical experts over the years in the correlation between the product and the adverse effects, in an effort to impress the trier of fact with the strength of the inference that "it was the product that did it." Such proof would be substantially similar to the proof on which plaintiffs rely in establishing the producers' negligence. See notes 22-24 supra. 
losses as a means of reducing dislocation costs. If one assumes that defendants can adequately insure against liability, or are financially strong enough to survive uninsured liability, the loss spreading objective would be achieved nnore readily with judicial reliance on hindsight than with liability based on negligence. Indeed, on these assuunptions, almost any change im liability rules that increases defendants' exposure would promote loss spreading. However, one problein with justifying liability for unknown hazards on notions of loss spreading is the assumption that defendants will be able to insure or to survive without insurance. It is doubtful that liability for unknown risks could adequately be insured against. Moreover, although some manufacturers are financially strong enough to survive substantial liability in excess of coverage, many are not. ${ }^{121}$ Certainly, some losses are large enough to crush even the strongest manufacturers. ${ }^{122}$ Thus, althougli producers are much more efficient insurers than are consuuners with respect to manufacturing defects, they nay be no more, or perhaps even less, effcient than consumers with respect to unknown design hazards.

On balance, it is difficult to see how judicial reliance on post-distribution imcreases im knowledge of product design hazards would promote social utility. Clearly, such a forn of strict liability would not achieve the objectives of inarket deterrence or transaction cost reduction. Whether it would reduce accident costs by increasing incentives for manufacturers to invest im product testing, or whether it would reduce dislocation costs by spreading losses effectively, are questions to which the answers are not so clear as proponents of strict liability for unknown hazards have claimed.

121. The premise here is that it will be impossible, except on a "claims made" basis, to insure against the catastrophic losses that might occur. See notes $102 \& 106$ and accompanymg text supra. One implication of strict liability based on hindsight is clear: only the largest and most financially sound enterprises are likely to survive. See Pratt \& Parnon, Diagnosis of a Legal Headache: Liability for Unforeseeable Defects in Drugs, 53 ST. JoHN's L. REv. 517, 537 n.85 (1979). Even if one accepts this conclusion, the imposition of potentially crushing liability may be defended. For onc thing, government may be expected to aid im some cases. For another, even for enterprises that cannot count on governmental assistance, it can be argued that no oue would be forced to gamble. Managers can take their skills to other corporations, and shareholders are free to invest elsewhere or to diversify their holdings in order to preserve their economic well-being. Thus, to the extent that the modern corporate structure facilitates the rational bearing of risks, producers liave an advantage, compared with consumers, that may justify allocating even potentially crushing liabilities to them.

122. In the so-called "Agent Orange" litigation, in which thousands of persons who served in the armed services during the Vietnam War are sumg the manufacturers of the defoliant "Agent Orange" for imjuries allegedly caused by that product, the aggregate damages sought exceed several multiples of the combined net worths of the defendants. See In re "Agent Orange" Prod. Liab. Litigation, 635 F.2d 987, 989 n.5 (2d Cir. 1980) (one plaimtiff asserted damages "in the range of $\$ 4$ billion to $\$ 40$ billion."). 


\section{Would Such Reliance Promote Fairness?}

The task here is to identify what makes strict liability for unknown hazards more, or less, fair than strict liability for manufacturing defects. The consumer expectations rationale appears to lend support for strict hability for unknown hazards, although it can be argued that consumers expect some unknown hazards in new products. Consumers' expectations as to design hazards are similar to their expcctations as to manufacturing defects: such hazards may be present, but "it won't happen to ine."123 However, in the context of unknown design hazards it is not clear that the conduct of the manufacturer is primarily responsible for creatimg the consumers' expectations of safety. A manufacturer exercises control over the quality of his products by monitoring the defect rate; when the manufacturer assures consumers that its products are "high quality," the advertisement helps to create the expectation that dangerous defects do not exist. In contrast, individual manufacturers exert less control over the limits of knowledge regarding product design risks; the "it won't happen to me" attitude witl respect to unknown and unknowable hazards inay be less the creation of advertising than a reflection of the human tendency to deny our mortality. ${ }^{124}$

It is not clear that the other fairness rationales apply to strict liability for design defects unknown at time of distribution. In contrast to producers' quality control decisions affecting manufacturing defect rates, which arguably amount to the deliberate taking of plaintiffs' physical well-being, it is difficult to see how the decision to market a product believed to be free of hazards involves the deliberate taking of the plaintiff's well-being. To be sure, producers know, as do users and consumers, that there is always some chance that any product design carries with it a generic hazard that testing has not revealed. Indeed, if a producer handles a large number of product designs, the occasional bad design is similar to the occasional defective product from one design. ${ }^{125}$ But for those producers who carry a limited number of different product designs, all of which are carefully tested before

123. See generally G. CALABRESI, supra note 53, at 56; Hogarth, Cognitive Processes and the Assessment of Subjective Probability Distributions, 70 J. AM. STATISTICAL Assoc. 271 (1975).

124. The expectations of safety in prescription drugs may derive from the fact that the federal government heavily regulates pharmaceutical manufacturers, rather than froin inanufacturers' advertising. If this is true, it diminishes the force of the plaintiff's claim against the manufacturer on fairness grounds. Moreover, these are defects which were unknown to the manufacturer as well as to the consumer.

125. Professor Epstein insists that the effccts on others of a nounegligent actor's conduct necd not be deliberate for his victim to have claims against the actor based on fairness. See note 79 supra. 
distribution, it is difficult to see how the taking of the consumers' wellbeing can be said to be deliberate.

Compared to the case of a manufacturing defect, the benefits of a product are less likely to match its burdens when it has an unknown design hazard. Imposing strict liability for unknown hazards causes a significant portion of the financial burdens of accidents to be delayed and borne by users and consumers of products other than those that caused the harm. To some extent, of course, the shifting of the financial burdens of product-related accidents occurs even with respect to manufacturing defects. ${ }^{126}$ Similarly, the later consumers, who bear the burden of higher prices for the new products, can be said to benefit from the discovery of previously unknown hazards. ${ }^{127}$ However, since strict liability for unknown risks shifts some of the costs forward to purchasers of completely different products, so that one class bears the burden while another receives the benefit, the benefits/burdens rationale may not be valid. ${ }^{128}$ To this consideration may be added the factor that in the substantial percentage of unknown risk cases imvolving prescription drugs, the risks to bystanders will be practically nonexistent. If they are affected at all, bystanders may actually benefit from the consumption by others of prescription drugs. ${ }^{129}$ Of course, the other significant category of products to be accompanied by unknown risksindustrial chemicals - is more likely to expose nonuser bystanders to risks of injury. However, taken in the aggregate, the bystander problem may be less significant in cases with unknown generic risks than in cases with manufacturing defects.

On balance, strict liability for unknown hazards is not well supported by the same fairness rationales that appear to lend support to strict liability for manufacturing defects. Although consumers suffer disappointed expectations upon the discovery of unknown generic

126. See Morris, supra note 103.

127. The earlier consumers function as "guinea pigs" for the benefit of those who follow.

128. The point here is that the "guinea pig" aspects, see note 127 and accompanying text supra, are often likely to be undercut. For example, assune that a drug is marketed to reduce high blood pressure. Unknown to anyone, the drug causes blindness. Many people consuine the drug over a five year period, and a few lose their sight. Eventually, the link between the drug and the blindness is discovered, and the drug is reinoved froin the inarket, but the drug company, $M$, is lield strictly liable for the blindness caused by the drug. The benefits of this discovery are shared by everyone who later suffers from high blood pressure and might have consumed the earlier, dangerous drug. This class of beneficiaries will include many who never purcliase a substitute high blood pressure drug from $\mathrm{M}$. On the other hand, the financial burden of the blindness costs will be borne by the later purchasers of M's products, including purchasers of products liaving nothing to do with high blood pressure. Indeed, if $M$ does not market a substitute high blood pressure drug, none of the beneficiaries of the discovery of the blindness hazard will later be required to bear the financial burden; that burden will be berne entirely by later purchasers of M's products who do not benefit from the discovery.

129. For example, the prescription drug may prevent the spread of contagious disease. 
hazards, so do manufacturers. This tends to create more of a sense of the producer and the consumer being victims of fate than of the latter being the victim of the former. Moreover, the mability of manufacturers to discover and control unknown design hazards makes it more difficult to conclude that manufacturers have deliberately imposed defective design choices on consumers in the same manner as they impose deliberate decisions about defect rates. Finally, strict liability for unknown hazards may actually create unfairness for later product puchasers who are forced to pay for harm caused earlier by altogether different products.

\section{Should Courts Rely on Post-Distribution Increases in Knowledge of Risk Reduction Techniques?}

There is less support for this form of reliance on hindsiglt among courts and commentators than there is for reliance on post-distribution knowledge of product-related hazards. Although some writers and a few courts have espoused liability for post-distribution developinents in risk reduction techniques, ${ }^{130}$ Deans Wade and Keeton and their followers draw the line at imputimg only time-of-trial knowledge of product hazards to manufacturers. ${ }^{131}$

\section{Would Such Reliance Promote Utility?}

Strict liability is not necessary to pressure manufacturers to invest in risk reduction researcl. Although the absence of legal pressures may result in inadequate investinent in testing for product-related liazards, profit incentives in the market sliould pressure producers to invest adequately in the development of risk reduction measures. ${ }^{132}$ Apart from liability effects, discovery of product-related hazards generates information with little profit; thus, it can be argued that unless producers are pressured by liability rules, they will not invest adequately in discovery efforts. ${ }^{133}$ In contrast, the discovery of risk reduction measures is typically accoinpanied by the securing of property rights such as patents, which provide the discoverer with significant competitive advantages. ${ }^{134}$ Of course, strict liability might provide incentives for manufacturers to recall and modify previously distributed durable goods

130. See notes 47-48 and accompanying text supra.

131. See notes $43-44$ and accompanying text supra.

132. See Schwartz, supra note 5 , at 485 \& n.281.

133. See notes $89-91$ and accompanying text supra. Imposing strict liability for unknown hazards may create other incentives for producers to beliave inefficiently. See notes 92-96 and accoinpanying text supra.

134. These subsequently discovered risk reduction techniques are the "better inousetraps" of the old adage, with respect to which patent rights are usually obtainable. See generally A. DELler, Deller's Walker on Patents (2d ed. 1964). 
once new risk reduction measures are discovered; ${ }^{135}$ but given the high costs to producers of such activities, it is unlikely that producers would behave very differently in this regard if strict liability were imposed. ${ }^{136}$

Further, there is little reason to beheve that market deterrence would be achieved by imposing strict liability on manufacturers for their nonnegligent failure to mcorporate risk reduction measures that were unknowable at the time of distribution. The practical impediments to achieving such an objective, described im the earlier treatment of liability for unknown product hazards, would not be overcome in the risk reduction context. The saine inability to predict technological developinents would cause a system of strict liability based on subsequently discovered risk reduction measures to achieve market deterrence only clumsily, if at all. ${ }^{137}$

An interesting question is whether strict liability for the failure to incorporate risk reduction techniques would promote allocative efficiency assuming that the practical limitations could be overcoine. Unlike the purchaser of a product with an unknown hazard, the purchaser of a durable product free of any unknown hazards is aware at the time of purchase of the product's risks and benefits. Even though the design of the product inay later be inade safer by a risk reduction technique discovered after the purchase, the informed purchaser of the durable goods will have made a cost-effective decision to purchase the product. ${ }^{138}$ When the purchaser has balanced the risks and benefits, he lias made the most efficient choice possible at the time, and the possibility of future risk reduction does not inake it less efficient. Tlierefore, liability for failure to incorporate risk avoidance measures would not improve efficiency. ${ }^{139}$

A source of social waste inay be identified by focusing on the avoidability of the hazards when the post-distribution discovery of risk reduction techniques could have prevented the plaintiff's injury. Assuming that purchasers of durable goods generally underassess the accident cost implications of long term commitments to new

135. See note 17 and accoinpanying text supra.

136. For a description of the costs involved, see FiNAL REPORT, supra note 103, at IV-7 to IV-

9.

137. See notes 101-15 and accoinpanying text supra.

138. Although consumers are frequently misinformed as to the risks and benefits, they know better than anyone else what they want. When they have access to accurate information regarding risks and beuefits, consumers reach efficient decisions regarding product consumption. See notes 73-75 supra.

139. See note 8 supra. Of course, if an improved substitute is known to be "just around the comer," then it will affect decisions to consume riskier products; some consumers at the margin will decide to wait for the improvenent. But in that case, the improved substitutes really are available to the consumers who feel they can afford to wait for them. 
technology, ${ }^{140}$ or that these purchasers generally act inefficiently even on accurate assessinents, ${ }^{141}$ social waste is generated when the purchasers of such products find themselves "locked into" outdated, dangerous technology in ways that inhibit them from switching to safer alternatives when they become available. ${ }^{142}$ To the extent that such waste occurs, a system of market deterrence aimed at its reduction would be justified.

The major difficulty in devising such a system is determining the appropriate signal, in the form of increases in product prices, to send to purchasers. The misallocation of resources occurs not as a result of purchasers underestimating the accident costs associated with the available products, but as a result of their underestimation of the benefits to be derived from soon-to-be-available substitutes for those products. ${ }^{143}$

140. See notes $62,101 \& 123$ and accompanying test supra. The text here refers specifically to durable products because those produets constitute a significant percentage of the cases involving subsequently discovered risk reduction techniques. See note 8 supra.

141. It inay seem odd to posit this situation here, given the earlier assumption that consuners will act efficiently when supplied with accurate information. See note 138 and accompanying text supra. But in cases involving subsequently developed risk reduetion techniques, frequently the products are machines purchased by employers for use by employees. One can assuine a certain degree of employer indifference to employee well-being, albeit checked by workers' compensation insurance. Of course, this indifference would also reduce the attractiveness to employers of presently available risk reduction measures; but at least the would-be victims in those cases would be employees presently on the scene and able to pressure the employer to make reasonable machinery purchases. In contrast, the would-be victims in the cases involving later-developed risk reduction techniques are not present, and therefore cannot exert pressure on employers.

142. One must take care in talking of purchasers being "locked into" older technology. When an improved product is developed, the demand for the older substitutes drops. (In terms of figure 1 in note 108 supra, the demand curve $D P$ for the older product $P$ moves to the left.) It follows that those who purchased the older technology will suffer an economic loss in the form of a drop in the value of the older technology on the used-product market. Assuming the products in question are transferable at small transaction costs, however, once that loss occurs it no longer functions as a disincentive to switching to newer technology. If a rational person coming fresh to the scene would purchase the new technology to perform the same tasks as the earher purchaser of the old technology is peforming with the old, then the earher purchaser will sell the old and buy the new. As one writer has explamed:

In either event, the continumg, fixed costs on the old equipment-the depreciation that may not yet have been fully recovered, the return on the net investment not yct fully written off, interest on the debt already incurred-are irrelevant to the decision [whether to switch to the new, improved equipinent]. Sunk costs such as these are bygoncs, unchangeable past history, and best forgotten.

1 A. KaHN, The Economics of Regulation 118 (1970).

It follows that in order to speak sensibly of being "locked into old technology" in the present context, one must introduce fairly high transaction costs that cause the earher purchaser of the old technology to decide not to switch to the new when new purchasers engaged in similar activities would rationally choose the new over the old. Stated differently, the earlier purchaser must be in a position where the old equipinent is worth significantly more to him than sucl equipment will fetch in the used-product market.

143. These benefits would assume two basic forms: (1) accident costs presently incurred but later proven to be avoidable; and (2) increases in productivity presently foregone but later proven to be attainable. Tort law has traditionally focused on the accident costs part of the equation; but 
Ideally, purchasers should be educated regarding the probabilities of various products being improved. Consumer education should result in a decrease in the demand for products which are likely to be improved. ${ }^{144}$ However, assuming that such efforts at education will never be made, liability might be imposed on manufacturers for a portion of the social costs generated by purchasers' inability to assess the likelihood of product improvement.

When the producer is subject to strict liability, products requiring long term commitments to dangerous technology become relatively expensive and suffer a competitive disadvantage in the market, thereby reducing wasteful commitments to such products. The social costs for which a manufacturer of a durable product might be held liable would mclude accident costs that were avoidable by cost-effective risk reduction techniques that became available during the norinal useful life of the product and before the plamtiff was injured. ${ }^{145}$ For reasons developed in the preceding analysis of strict liability for unknown risks, the plamtiff should not be required to show that the purchaser would not have bought the product if he had known that the avoidance ineasures would subsequently be developed. ${ }^{146}$ The plaintiff should, however, be required to show that the purchaser's commitment to the old technology was the proximate cause of his injury. Recovery should be denied when the defendant shows that a cost-effective switch to the newer, safer technology was available to, and refused by, the person in control of the product when the risk avoidance measures became available. ${ }^{147}$ If a cost-effective switch was available, then the purchaser was not

from the broader perspective of achieving allocative efficiency via market deterrence, future gains in productivity inust be considered. See note 6 supra.

144. See note 139 supra.

145. In some cases, the question of whether the new technology would have avoided the plaintiff's injuries would be difficult. The inost difficult cases would be those in which the safety gains are shght and therefore a real question exists as to whether the plaintiff would have been injurcd anyway. Consistent with the foregoing analysis, one might consider allowing recovery of costs other than accident costs. Plamtiffs might, for example, be allowed to recover for reductions in market values of durable goods caused by the introduction of newer, safer alternatives. This "benefits forgone" element of recovery would correspond to the second form of benefit to be derived from new technology (here translated into a cost of being stuck with the old technology). See note 143 supra. For consumables, the ineasure of recovery for "benefits forgone"is soinewhat more difficult.

146. See notes 109-11 and accompanying text supra.

147. The type of case in which this proximate cause requirement would be most questionable would be one involving an cinployer who purchases a machine for use by his employees. The concern ovcr underassessinent of product improvability stems in part from an assninption that employers will tend to ignore their employces' welfare when purchasing machinery. See note 141 supra. It would undercut the inarket deterrence objective of forcing einployers to take this into consideration if the plamtiff were to be denied recovery because the employer refused to act in the plaintiff-employee's interest. Of course, the proximate cause test here suggested, even if supportable in principle, would be difficult to apply in actual cases. What, for exainple, is a "cost effective switch"? See note 142 supra. Would the court inquire into the purchaser's financial situation at 
locked into the older, dangerous product; liability in such cases would not help to eliminate the social waste created by commitments to dangerous technology.

The discussion to this point has been limited to durable products. The saine approach to liability for later discovered risk reduction techmiques nay be apphed to consumables, such as prescription drugs. In this context, it is more appropriate to speak of the wasteful commitinents to dangerous products as being "overly hasty," rather than "long term." A system of strict hability aimed at deterring consumers from buying dangerous but likely to be improved consumables would seek to eliminate overly hasty commitments to dangerous products. The problem is to define the scope of liability so as to achieve the market deterrence objective. Clearly the approach suggested in connection with durable products would be inappropriate. The test for durable products focuses on the availability of a cost-effective, safer alternative between the time of purchase and the time of injury. The plaintiff who is injured by a consumable product typically suffers injury the noment the product is consumed, in that the negative effects of consumption cannot be reversed. Thus, to require the plaintiff to show that the risk reduction measure became available after the purchase but before he was injured would be to deny recovery to all plaintiffs who consume the product at the time of purchase. What is needed is some basis, other than time of plaintiff's injury, for determining the relevance of later improvements in technology. The "haste" involved in "overly hasty" commitment to dangerous consumable products can only be determined relative to the costs to the consumer of deferring consuinption. This suggests a test based on whether the plaintiff would have consumed the product he knew to be dangerous had he been able to foresee when the discovery of the risk reduction ineasure would occur. However, such an approach would fail to achieve the market deterrence objective. ${ }^{148}$ What is required is the construction of a hypothetical "reasonably prudent consumer." Liability would depend on whether a reasonable consumer would have deferred consuming the product if that person had known when the risk reduction ineasure would be discovered. If the reasonable consumer would have deferred consumption, the plaintiff should recover notwithstanding the fact that the particular plaintiff would have consuned the product anyway.

This writer has no reason to beheve that the strict liability approaches just described would work any better im achieving efficiency through market deterrence than the systein of liability for unknown

the time the switch to newer technology became possible? The difficulties presented by these questions suggest that the proximate cause inquiry would be unmanageably complex.

148. See notes 107-11 and accompanying text supra. 
hazards. The practical problems involving the availability of msurance and the development of a workable standard of liability would surely limit the ability of strict hability to promote efficient allocations. ${ }^{149}$

There is little reason to beheve that strict liability based on postdistribution increases in knowledge of risk reduction techniques would reduce transaction costs by simplifymg legal rules. Certainly the hability tests described in the preceding analysis would not achieve that objective. In fact, to the extent that courts were called upon to decide questions such as whether purchasers of durable products have been "locked into" dangerous technology, or whether decisions to consurne hazardous products might have been deferred if consumers had known of pending discoveries of risk reduction techniques, the costs of litigation would be mcreased. ${ }^{150}$

Finally, strict liability in this context would encounter the saine difficulty in promoting loss spreading that is encountered by strict liability for unknown hazards. In contrast to the manufacturer's ability to msure agamst loss caused by manufacturing defects, the superiority of producers as risk bearers is questionable in that they can neither predict nor control technological developinents.

\section{Would Such Reliance Promote Fairness?}

If strict liability for unknown generic product hazards can be justified on the basis of the disappointment of consumer expectations, then it follows that some form of strict liability for failure to incorporate unknown risk reduction techniques is also justified. The user or consumer $\mathrm{m}$ the risk reduction case knows froin the outset of the hazards that eventually materialize in harn; but he does not know that the hazards will soon be discovered to be avoidable. If the risk avoidance measures are discovered too much later to have helped the plaintiff, their later discovery is clearly irrelevant. However, if the discovery of the risk reduction ineasures occurs soon enough to help the plaintiff, but for his prior commitunent to hazardous technology, his situation is very similar to that of the plaintiff harned by a previously unknown product hazard. In both cases, limits on knowledge at the time of

149. Some advocates of strict liability based on post-distribution knowledge of unknown hazards reject the same theory of liability for post-distribution knowledge of risk reduction techniques. See notes 43-44 supra. Yet those who are willing to overlook impracticalities in advocatnig strict liability for unknown lrazards must explain why these forms of rehance on hindsight are any less desirable in theory. If there is no satisfactory answer to the question "Why this far and no further?," there is even more reason to doubt the legitimacy of courts taking the first step toward strict liability for unknown product hazards.

150. Moreover, such questions are probably beyond the capacities of courts to answer on a case-by-case basis. See Henderson, Judicial Review, supra note 46. 
purchase cause the plaintiff to suffer harm; the plaintiff is trapped by inadequate information in either case.

A paradign case of an unknown risk is the consunption of a drug for high blood pressure that causes, but is not known to cause, cancer. When the consumer later learns, along with everyone else, that the cancer that is killing him was caused by the drug, he has a right to feel disappointed by the product. ${ }^{151}$ A paradigin case of a subsequently discovered risk reduction technique is the consumption of a drug for high blood pressure, known to cause cancer in a certain percentage of instances. The patient takes the drug because the dangers from his high blood pressure are greater than the risk of getting cancer. ${ }^{152}$ The patient develops a cancer froin the consuinption of the drug. Soon after the patient's consumption of the drug, a discovery reveals that an adjustinent in the drug formula eliminates the cancer risk without significantly reducing the drug's benefits. A reasonable person in the position of the patient would have deferred treating his blood pressure with the drug if he had known of the imminent developinent. Is not the consuiner in this second case as entitled as the consuner in the first to claim unfair surprise? ${ }^{153}$ In the first case the victim innocently but fatally believed that the drug was safe; in the second, the victim innocently but fatally believed that no safer alternative would be available in time to lielp him. If the consumer expectations rationale justifies strict liability in the first case, it justifies strict liability in the second. ${ }^{154}$

The "deliberate taking" and the "benefits/burdens" rationales apply here in inuch the same fashion as they do to strict hability for unknown product design hazards. It is inore difficult in this context than in the context of inanufacturing defects to see how a producer could be said to liave deliberately imposed on others costs of which he could not have been aware. ${ }^{155}$ Moreover, imposing strict hability for failure to incorporate unknown risk reduction techniques would delay some financial burdens of accidents and impose thein on subsequent users

151. Compared with manufacturing defects, the disappointment might not be directed so much against the producer in this situation as against fate or the government. See note 124 and accompanying text supra.

152. Although the cases involving subsequently developed risk reduction measures are rarely drug cases, this hypothetical is employed so that it may be compared with the drug hypothetical involving a previously unknown cancer hazard.

153. Professor Schwartz has concluded that the consumer in the second case has no basis to claim unfair surprise. See Schwartz, supra note 5, at 485-86.

154. In this hypothetical, the subsequent technological breakthrough eliminated the risk of cancer. If the risk were only shightly reduced, a difficult question would be presentcd whether thc plaintiff might have been injured even if he had waited. See note 145 supra. In the context of consumable products, however, if the reduction in risk is only slight, a reasonable consumer would not have deferred consumption. See text following note 148 supra.

155. See text following note 124 supra. 
and consumers who will not have benefited from the earlier productrelated activities. ${ }^{56}$

On the other hand, this form of strict liability may be more justifiable than is strict liability for unknown hazards on the ground of shifting losses from bystanders to users and consumers. For one thing, more of the cases involving post-distribution increases in knowledge of risk reduction techinques involve durable goods than consumable goods. ${ }^{157}$ Thus, a significant class of persons harmed by long term commitments to dangerous technology consists of employees who operate old inachinery. These employees inay be viewed as bystanders because they neither participated in nor derived benefits from the earlier decisions to make these commitments. The use of a rule of strict liability to shift losses may liave greater justification in the case of durable machinery. ${ }^{158}$

\section{Should Courts Rely on Post-Distribution Changes in Attitudes?}

As the preceding analyses demonstrate, considering different types of post-distribution imcreases in knowledge separately is helpful because the two types of knowledge differ in effectiveness: product hazards affect people whether they are known or unknown, but risk avoidance measures have no effect until they are known. ${ }^{159}$ Attitudes are effective whether they relate to hazards or to risk reduction teclniques. Moreover, one type of attitudinal change tends to be linked with the other: as society becomes less tolerant toward product hazards, it necessarily becomes more tolerant toward risk reduction measures, and vice versa. Thus, considering changes in attitudes to-

156. See notes 102-06 and accompanying text supra.

157. See note 8 and text accompanying note 6 supra.

158. The cases in which appellate courts have viewed employees as the helpless victims of machine designers' indifference to safety are collected in Henderson, Judicial Review, supra note 46, at 1566 n. 148.

There is another sense in which the nonuser/nonconsumer plaintiffs in cases involving subsequently discovered risk reduction techniques are bystanders. In the traditional context of strict hability for manufacturing defects, the bystander-plaintiffs are bystanders only in the space dimension. They neither use, consume, nor directly derive benefits from use or consumption; but they can be said to "benefit" in a broad sense, as contemporary members of a society that generally benefits from having useful products available. In the present context, in contrast, these bystander-plaintiffs are bystanders not only in space but also in time. Thus, a plaintiff who is injured twenty years after the purchase of a dangerous durable product can less easily be said to benefit from the fact that such products were available twenty years earher. In connection with bystander plaintiffs, the time dimension introduces an added fairness consideration supporting strict liability. Of course, imposing strict liability will not cause all of the costs to be borne by prior purchasers at the time of origimal distribution. See notes 102-06 and accompanying text supra. But to the extent that some of these later accident costs are anticipated and imposed on the origimal purchasers of dangerous durable products, principles of fairness liave been respected.

159. See note 8 and accompanying text supra. 
ward hazards separately from changes in attitudes toward risk avoidance measures is not particularly helpful, and will not be attempted.

\section{Would Such Reliance Promote Utility?}

The major contribution of reliance on post-distribution attitudes would be to pressure manufacturers and purchasers of durable products to take into account the possibility that commitments to dangerous technology may come into conflict with attitudes toward product-related risks. The objective of such reliance would be to reduce commitments to dangerous durable goods by requiring producers to give weight to attitudinal trends favoring product safety.

In contrast to the other foruns of strict hability already considered, strict liability based on post-distribution shifts im attitude is likely to change the way products are designed and marketed rather than merely to imduce manufacturers to insure against contimgencies. Once shifts in attitudes are anticipated, it is within the producer's power to conform his design and marketing decisions to those anticipated shifts. ${ }^{160}$ In contrast, predistribution limits on knowledge are automatic constramts on design and marketing decisions. For example, even if the producer can predict that risk-avoidance techinques will be developed, those measures may not be available at the time of distribution.

In theory, the risk control potential of strict hability based on postdistribution changes in attitude is substantial. Producers are not hable under negligence law for failing to foresee trends in consumer attitudes toward product safety. ${ }^{161}$ Market incentives to anticipate such trends are weak because the purchasers of durable products are likely to concentrate on present benefits, placing little or no value in investing im safety measures that are ahead of their time. ${ }^{162}$ Demand for presently justifiable risk reduction techniques is relatively strong because such techniques allow users of durable goods to retam the benefits of technology while reducing their costs, including accident costs, of operation. ${ }^{163}$ However, investing in safety measures that are not yet warranted by the attitudes prevailing at the time of purchase means

160. Of course, public attitudes may reflect desires for levels of product safety that are not possible at the time of distribution; but sucli cases are treated in this analysis as limits of knowledge situations. Thus, given the approach in this Article, it is true that once attitudinal shifts are perceived they can be accommodated. The public attitudes of concern here are attitudes relating to available alternatives.

161. See notes 14-16 supra. Cf. note 22 supra (manufacturer's duty to anticipate advances in knowledge).

162. One reason for this tendency may be the fact that busimess managers, who make many of the purcliases of durable products, are exposed to market pressures to perform well in the short run. See generally Fama, Agency Problems and the Theory of the Firm, 88 J. PoL. EcoN. 288, 29192 (1980).

163. Of course, to the extent that business managers ignore the well-being of their einployees, 
that the consumer is sacrificing short run efficiency in favor of long term efficiency. From the long term perspective such sacrifices are rational; ${ }^{164}$ but purchasers left to their own preferences are likely to act only, or primarily, on the basis of short term benefits. ${ }^{165}$

The difficult task is to work out a test for liability that will effect an efficient compromise between short run and long run interests. Clearly, allocative efficiency would be diminished by requiring a producer to reflect $i m$ his design and marketing choices the likelihood that at some point in the future, im a trial occurring after the useful life of the product, the product might be deemed unreasonably dangerous in light of then prevailing attitudes. On the other hand, social waste may occur because consumers, having underestimated the likelihood that attitudes will change, buy products that will come to be viewed as unreasonably dangerous. Liability could be imposed in a maimer similar to that suggested in the analysis of subsequent development of risk reduction techniques. Manufacturers would be held liable for injuries proximately caused by the limited ability of purchasers of the products to shift to safer alternatives that better reflect changed attitudes toward product safety.

One effect of such an increase in exposure would be to pressure manufacturers to design durable products with better safety devices. Another possible effect would be to pressure manufacturers to design products to have shorter lives and to accommodate safety devices as those devices come to be required by prevailing attitudes. A third effect might be to pressure inanufacturers to make greater follow-up and recall efforts. ${ }^{166}$ Finally, strict liability based on post-distribution changes in attitudes might pressure manufacturers to educate purchasers regarding the long range implications of commitments to dangerous technology, thus increasing demand for products whose designs anticipate trends favoring greater safety. ${ }^{167}$

Beyond affecting manufacturers' design and marketing choices, a rule of strict liability for post-distribution shifts im prevailing attitudes would induce manufacturers to insure agamst their increased liability. For the reasons developed in previous discussions of other forıns of judicial reliance on hindsight, it is unlikely that effective levels of mar-

the benefits here referred to will be of small consequence to the purchasers of industrial machinery. See note 141 supra.

164. However, high rates of interest and inflation reduce the desirability of sacrificing today in order to receive benefits tomorrow.

165. See note 162 and accompanying text supra. It is reasonable to assume that the same users and consumers who underestimate the risks that accompany products, see note 62 supra, also tend to be shortsighted in this regard.

166. See notes 17,136 and accompanying text supra.

167. See text accompanying notes 143-44 supra. 
ket deterrence would thereby be achieved. Instead, the tendency would be for substantial portions of the liability costs generated by old, dangerous technology to be borne by subsequent purchasers of newer, safer products. ${ }^{168}$

The major drawbacks to this form of strict liability relate to the premises on whicl it rests-namely, that our society is in an irreversible trend favoring product safety and that purchasers of durable products tend to underestimate the strengtli and direction of that trend. If either of these assumptions is false-if the trend in attitudes were to swing in the direction of risk preference, for example ${ }^{169}$-then the effect of such a form of strict hability would be to reduce, rather than to imcrease, allocative efficiency. ${ }^{170}$ Moreover, even if the assumptions are vahd, it appears unlikely that imposing strict liability on the basis of post-distribution shifts in attitudes would promote social utility. Any liability test meeting the theoretical criteria outlined above would be so vague and difficult to apply as to generate unacceptable transaction costs. Any liability test that might avoid those difficulties, such as the time-of-trial hindsight test urged by a mmority of courts and commentators, ${ }^{171}$ would cause every durable product eventually to become legally defective, detracting from rather than enhancing allocative efficiency.

\section{Would Such Reliance Promote Fairness?}

It is difficult to see low rehance on post-distribution shifts in prevailing attitudes would disappoint the expectations of the original purchaser of the product in question. Unlike post-distribution increases in knowledge, later shifts in attitudes cause shifts in the expectations themselves. It is the subsequent expectations, not the original, that are disappoimted. With respect to the "deliberate taking" and the "benefits/burdens" rationales, the analysis of post-distribution shifts in attitudes parallels earlier analyses of the other forns of judicial reliance on hindsight. A manufacturer could not be said to have deliberately taken

168. See notes 102-06 and accoinpanying text supra.

169. It is possible that the assumption of a trend favoring safety is false. It is largely based on the expressions of public officials such as judges and administrators. See note 10 supra. These exhortations in support of greater safety may be a reaction against, rather than an affirmation of, the attitudes of a inajority of the public. Indeed, we inay be in the beginning stages of a consumer revolt against paternalistic regulatory activity. See generally Gilder, Prometheus Bound, 257 HARPER's 35, 41 (Sept. 1978) (disadvantages of government policies that suppress uncertainty); Mayer, Exploring Sociological Theories By Studying Consumers, 21 AM. BEHAvioraL ScIENTIST 600,609 (1978) (noting recent consumer attempts to stop consuner protection programs).

170. If risky products are taxed heavily during a period in which public attitudes are moving toward greater acceptance of product-related risks, the society will make wasteful overinvestunents in safety.

171. See notes $47-48$ supra. 
the well-being of others by distributing a product without knowing that it would one day be viewed as defective. And by requiring later purchasers of different products to pay for the consequences of earlier design and marketing choices, this forın of strict liability would create, rather than eliminate, unfairness among classes of users and consumers. ${ }^{172}$

On the other hand, the bystander problem is especially acute in this context. In the traditional strict liability contexts in which attitudes toward product-related risks are assumed to be constant, bystander victims can be assumed to share, at least in a general way, the values reflected in the product choices that affect them. To be sure, in cases involving later discovered risk reduction techniques some of thein are "future bystanders" when the products are designed and marketed; they are bystanders in time as well as space. ${ }^{173}$ Still, if attitudes hold constant, the values reflected in the design and marketing choices are values they are presuined to share. With attitudes changing through time, however, the "future bystanders" are bystanders in still another sense. Not only have they not benefited from the product choices inade earlier, the later victims do not even share the values that led to those choices.

Although products liability commentators have not yet addressed this subject, writers in other fields have. Moral philosophers have examined the duties owed by one generation to the next. ${ }^{174}$ As a practical matter, the time spans involved in products liability cases are unlikely to encompass generations. Philosophically, however, the issues posed by products liability are similar to those traditionally addressed in the intergenerational context-that is, whether today's consumers should be obligated to sacrifice in order to protect the interests of future consumers. This issue has been raised frequently by legal commentators in connection witl the use of scarce environmental resources. In the environmental context, intergenerational duties have been fairly widely recognized in principle. ${ }^{175}$

\section{CONCLUSION}

Changes through time in knowledge and attitudes create the potential for waste and unfairness in our systein of products liability. That courts and cominentators should seek ways of reducing these byproducts of technological evolution is understandable and admirable.

172. See notes $102-06$ and accompanying text supra. See also text accompanying note 156 supra.

173. See note 158 supra.

174. See, e.g. , J. Rawls, A Theory of Justice 284-93 (1970).

175. See R. Stewart \& J. Krier, Environmental Law and Policy 173-79 (2d ed. 1978). 
The question that inust be asked, however, is whether imposing strict liability on manufacturers based on hindsight will assist in reducing these negative effects of change. The answer that ennerges from this analysis is that it will not. It is doubtful that such liability would affect the conduct of manufacturers so as to reduce significantly the levels of risk; and there is little potential for enhancing efficient allocations through market deterrence. Transaction costs might actually increase when courts try to devise fair and sensible rules to accoinplish the goals of strict liability.

In the final analysis, one's reaction to proposals that courts rely on hindsight in these cases will probably depend on how one views the objective of loss spreading and the relevance of fairness principles. Those who advocate greater hability may be correct when they assert that large producers can survive even substantial losses, and therefore loss spreading can be accomplished without significant economic dislocations. ${ }^{176}$ A major problem with this view of the loss spreading rationale, however, is the fact that the products liability system is monstrously wasteful, with only a small portion of the liability insurance premiums being used to compensate accident victims. ${ }^{177}$ High administrative overhead might be acceptable if strict hability based on hindsight worked to reduce accident costs or to improve allocative efficiency. However, this analysis mdicates that strict hability would achieve neither of these objectives to any significant degree. Standing alone, therefore, judicial cost spreading must be rejected as an inadequate reason for imposing the kinds of strict liability considered in this Article. ${ }^{178}$

Regarding fairness, this writer voiced skepticism at the outset concerning its relevance to the question of whether strict liability should be imposed on unanufacturers who have exercised reasonable care in designing, producing, and marketimg their products. However, even if one assumes that strict liability for manufacturing defects is supported by fairness principles, it is not clear that strict liability based on hindsight is similarly supportable. One's view of the relevance of fairness in

176. See, e.g., Rheingold, Products Liability-The Ethical Drug Manufacturer's Liability, 18 RUTGERS L. REv. 947, 1016-17 (1964).

177. The Interagency Task Force estimated that only 29 cents of every premium dollar return to accident victims. The rest is absorbed as transaction costs. FINAL REPORT, supra note 103, at V-24 to V-25, V-67. Professor O'Connell is inore optimistic, but even his estimate is depressing: only 37.5 cents of every premmuin dollar are returned to victims. O'Connell, An Alternative to Abandoning Tort Liability: Elective No-Fault Insurance for Many Kinds of Injuries, 60 MiNN. L. Rev. 501, 511 (1976).

178. See Owen, supra note 56 , at 715 , and note 67 supra. Given the high overhead costs described in note 177 supra, one could view the loss-spreading rationale differently-as a means of effecting a wealth transfer from the poor to the rich. The consuming public contributes about 70 cents of every premium dollar to keep lawyers and adjusters busy and prosperous. 
this context will probably depend on one's view of the nature of the relationships among product manufacturers, purchasers, users, and consumers in our society. If one views product manufacturers as dominant, powerful actors who impose value choices on passive, unconsenting users, consumers, and bystanders, then the forms of strict liability considered in this Article are likely to be attractive on fairness grounds. If one views manufacturers as conduits through which the value choices of users and consumers find expression, ${ }^{179}$ and if one feels that product-related costs and benefits are fairly evenly distributed throughout our interdependent society, ${ }^{180}$ then primciples of fairness will seen less important in deciding whether or not to impose strict liability. Because this writer tends to agree with the latter view, he finds it difficult to support, on fairness grounds, those forms of hability that seem likely to result in the waste of scarce resources. ${ }^{181}$

Along with rejecting proposals for sweeping judicial reliance on hindsight, this analysis also rejects the more modest strict liability approach suggested by Deans Wade and Keeton. Again, it is difficult to see what their approach would accomplish beyond loss spreading as an end in itself and vindication of the consumer expectations fairness rationale at the expense of treating some producers and subsequent consumers unfairly. It is somewhat puzzling that advocates of the WadeKeeton approach who have argued strenuously for strict hability for unknown risks have not considered seriously the other forms of strict liability based on hindsight. Perhaps the mechanical similarities between manufacturimg defects and unknown generic hazards have caused them to focus their attention on these aspects. Once these mechamical similarities are shown to be superficial, and the niore fundamental similarities among the varieties of hindsight are revealed, the

179. See note 138 supra.

180. See note 82 supra. The statements in the text may be a different way of expressing the position taken by Professor Fletcher regarding fairness in the law of torts-that is, that while fairness supports recovery in strict liability where the risks created by the defendant are nonreciprocal, no such support exists where the risks among those affected are reciprocal. See Fletcher, note 68 supra. Here, to be sure, we are talking about reciprocity among users and consumers; but if producers are viewed essentially as conduits, Fletcher's rationale seems to argue against liability. In a similar vein, Posner argues in favor of limiting liability to negligence on the ground that there is an "absence of systematic distributive effects" under that approach. See Posner, Efficiency Norm, supra note 83, at 506. Presumably, he would favor strict liabiliy if it could be demonstrated that the negligence approach led to systematic distributive effects.

181. The statement in the text is reminiscent of Calabresi's position that fairness (he uses the word "justice") operates as veto or constraint on efficiency concerns. See G. CALABRESI, supra note 53, at $24 \mathrm{n} .1$. This approach can be criticized on the ground that it weiglts the scales too heavily in favor of efficiency, and that results that are fair should bo sought regardless of their utility effects. For a criticisin of Calabresi's veto approach, see Dworkin, Efficiency, supra note 81. I will avoid the issue by insisting that the fairness case for strict liability based on hindsight lias not been made. 
decision to "go this far, but no further" appears arbitrary. In any event, consistent with the analysis in this Article, the 1nost appropriate response for courts would be to refuse to take even the limited step of imposing strict hability for unknowable hazards.

In arguing against holding manufacturers strictly liable in tort for their design and marketing choices, this writer does not mean to imply that the neghigence approach in these cases is working well. Indeed, the "reasonableness under the circumstances" standard is too vague to allow courts sensibly to review manufacturers' design choices, and more specific, workable standards of decision inust be developed by courts and legislatures if this branch of products liability is to survive. ${ }^{182}$ However, the answer to the difficulties encountered under a neghigence approach in design and warning cases is not for courts to impose on inanufacturers a grossly wasteful and unfair regime of strict tort liability. Anyone who believes that notions of fairness and loss spreading justify recovery in these cases should devise a no-fault compensation system that would, at least, return to accident victims a reasonable percentage of the premium dollars paid in. ${ }^{183}$

Even if the traditional negligence approach is improved by legislation, products liability will still involve probleins relating to the time dimension. Thus, courts will continue to give retroactive effect to judicial changes in the common law, ${ }^{184}$ and they will continue to allow triers of fact to rely on subsequently discovered hazards and subsequently developed risk avoidance teclimiques as circumstantial proof of producers' neghigence at the time of distribution. ${ }^{185}$ To a considerable extent, these indirect applications of hindsight are unavoidable. To atteinpt, for exainple, to apply a different set of legal doctrines in design and warning cases depending on when a particular product was distributed would be as unworkable as it would be unwise. ${ }^{186}$ And to exclude evidence of post-distribution increases in knowledge of hazards and risk reduction techinques would eliminate prejudice to the defendant

182. See Henderson, Judicial Review, supra note 46.

183. This writer would not favor such a drastic reform until more modest changes in the negligence system have been given a chance to work. See, e.g., Henderson, Manufacturer's Liability for Defective Product Design: A Proposed Statutory Reform, 56 N.C.L. Rev. 625 (1979); Henderson, Judicial Confusion, supra note 38.

184. See notes 27-31 and accompanying text supra.

185. See notes 23-25 and accompanying text supra.

186. See Note, supra note 27 , at 197-99. One solution to the change in law problem would be to change the law less often. See generally Epstein, The Static Conception of the Common Law, 9 J. Legal Stud. 253 (1980); Williams, The Static Conception of the Common Law: A Comment, 9 J. LEGAL STUD. 277 (1980). The trend toward statutory reform and codification of products hability law may help to bring stability to this area. See note 88 supra and notes 188-90 and accoinpanying text infra. 
only by creating greater prejudice to the plaintiff. ${ }^{187}$

Partly in response to the inevitability of hindsight-related prejudice to defendants in cases involving products distributed inany years before trial, several state legislatures have enacted statutes of repose establishing absolute bars to recovery in products liability actions brought inore than a stated number of years after first distribution. ${ }^{188}$ On balance, these statutes constitute harsher responses to the hindsight problein than is necessary. ${ }^{189}$ In lieu of statutes of repose, legislatures should consider a more flexible approach to the problems posed by the time dimension: the establishment of a presumption, rebuttable by the plaimtiff on clear and convincing evidence, that design and inarketing choices made more than a stated number of years prior to the bringing of suit were reasonable when inade. ${ }^{190}$ Were such a provision to be-

187. Evidence of post-distribution increases in knowledge constitutes circuunstantial proof that the hazards and the risks reduction techniques were discoverable earlier in the exercise of due care. To exclude such evidence altogether in order to prevent its misuse by juries is to deny plaintiffs access to otherwise legitimate, relevant proof of fault.

188. See, e.g., Ga. Code AnN. § 105-106(b)(2) (Cuin. Supp. 1980); Ind. Code AnN. § 34-420A-5 (Burns Cum. Supp. 1979); UTAh Code Ann. $\$$ 78-15-3 (1977). See also Colo. Rev. Stat. $\S 13-21-403$ (3) (Cum. Supp. 1978) (establishing rebuttable presumption that product was not defective and manufacturer not negligent); KY. REV. STAT. \$411.310 (Cum. Supp. 1980).

189. See, e.g., Blanchard \& Abrams, North Carolina's New Product Liability Act: A Critical Analysis, 16 WAKE FOREST L. Rev. 171, 196-203 (1980); Phillips, An Analysis of Proposed Reform of Products Liability Statutes of Limitations, 56 N.C.L. REv. 663 (1978); Twerski, supra note 13; Comment, Statutes of Repose in Products Liability: The Assault Upon the Citadel of Strict Liability, 23 S.D. L. REv. 149, 171-77 (1978). But see Note, Limiting Liability: Products Liability and a Statute of Repose, 32 BAYLOR L. REV. 137, 143-49 (1980).

190. This suggestion derives in part froin this writer's work in developing a products liability reform proposal appropriate for federal enactment. A version of this approach was contained in a bill introduced in the 96th Congress. See H.R. 7921, 96th Cong., 2d Sess. $\$ 9$ (1980).

As a beginning, the following statute miglit be considered for enactment:

(a)(1) In any products liability action a presumption shall arise that the plaintiffs harm was not caused because the product was negligently designed or marketed, or because the product was unreasonably unsafe in design or marketing, if the action was brouglit after the end of the louger of the following periods:

(A) The 10-year period beginning at the time of delivery of a product to its first purchaser or lessee who was not eugaged in the business of selling such product (including selling it as a component part of another product).

(B) The period (if any) during which the product seller expressly warrants that the product can be safely utilized.

(2) The presumption under paragraph (1) may be rebutted only by clear and convincing evidence.

(b) The presumption under subsection (a) shall not arise if the product seller intentionally misrepresented facts about the product or fraudulently concealed information about the product and such conduct was a substantial cause of the plaintiff's harm.

A few explanatory comments nay be helpful. First, other exceptions could be consideredfor exainple, the problem of cumulative negative effects froin repeated exposures to chemicals could be addressed explicitly. Second, the imderlying rationale for sucli a statute is that prejudice to defendants from reliance on hindsiglit is unavoidable in trials involving old products, and that some limit is necessary to eliminate some of the prejudice. Ten years is just a suggested period. Plaintiffs who can recover without any lielp from hindsiglit should be able to rebut the presumption. The statute reflects a judgment that it is better that a few arguably worthy plaintiffs lose in 
come law, it might help to counterbalance the negative and otherwise unavoidable effects of reliance on hindsight in design and warning cases.

close cases than many defendants be held liable undeservedly due to the unavoidable effects of hindsight. 